\title{
Assessment of health equity consideration in masking/PPE policies to contain COVID- 19 using PROGRESS-plus framework: a systematic review
}

Anindit Chhibber ${ }^{1}$, Aditi Kharat ${ }^{1}$, Dylan Kneale ${ }^{2}$, Vivian Welch ${ }^{3,4}$, Mukdarut Bangpan $^{2}$ and Nathorn Chaiyakunapruk ${ }^{1,5^{*}}$

\begin{abstract}
Introduction: There is increasing evidence that COVID-19 has unmasked the true magnitude of health inequity worldwide. Policies and guidance for containing the infection and reducing the COVID-19 related deaths have proven to be effective, however the extent to which health inequity factors were considered in these policies is rather unknown. The aim of this study is to measure the extent to which COVID-19 related policies reflect equity considerations by focusing on the global policy landscape around wearing masks and personal protection equipment (PPE).

Methods: A systematic search for published documents on COVID-19 and masks/PPE was conducted across six databases: PubMed, EMBASE, CINAHL, ERIC, ASSIA and Psycinfo. Reviews, policy documents, briefs related to COVID19 and masks/PPE were included in the review. To assess the extent of incorporation of equity in the policy documents, a guidance framework known as 'PROGRESS-Plus': Place of residence, Race/ethnicity, Occupation, Gender/sex, Religion, Education, Socioeconomic status, Social capital, Plus (age, disability etc.) was utilized.

Results: This review included 212 policy documents. Out of 212 policy documents, 190 policy documents (89.62\%) included at least one PROGRESS-plus component. Most of the policy documents ( $n=163,85.79 \%$ ) focused on "occupation" component of the PROGRESS-plus followed by personal characteristics associated with discrimination ( $n=4 ; 2.11 \%)$, place of residence $(n=2 ; 1.05 \%)$ and education $(n=1 ; 0.53 \%)$. Subgroup analysis revealed that most of the policy documents $(n=176,83.01 \%)$ were focused on "workers" such as healthcare workers, mortuary workers, school workers, transportation workers, essential workers etc. Of the remaining policy documents, most were targeted towards whole population $(n=30 ; 14.15 \%)$. Contrary to "worker focused" policy documents, most of the 'whole population focused' policy documents didn't have a PROGRESS-plus equity component rendering them equity limiting for the society.
\end{abstract}

\footnotetext{
* Correspondence: nathorn.chaiyakunapruk@utah.edu

${ }^{1}$ School of Pharmacy, University of Utah, Salt Lake City, UT, USA

${ }^{5}$ School of Pharmacy, Monash University, Subang Jaya, Malaysia

Full list of author information is available at the end of the article
}

(c) The Author(s). 2021 Open Access This article is licensed under a Creative Commons Attribution 4.0 International License, which permits use, sharing, adaptation, distribution and reproduction in any medium or format, as long as you give appropriate credit to the original author(s) and the source, provide a link to the Creative Commons licence, and indicate if changes were made. The images or other third party material in this article are included in the article's Creative Commons licence, unless indicated otherwise in a credit line to the material. If material is not included in the article's Creative Commons licence and your intended use is not permitted by statutory regulation or exceeds the permitted use, you will need to obtain permission directly from the copyright holder. To view a copy of this licence, visit http://creativecommons.org/licenses/by/4.0/ The Creative Commons Public Domain Dedication waiver (http://creativecommons.org/publicdomain/zero/1.0/) applies to the data made available in this article, unless otherwise stated in a credit line to the data. 
Conclusion: Our review highlights even if policies considered health inequity during the design/implementation, this consideration was often one dimensional in nature. In addition, population wide policies should be carefully designed and implemented after identifying relevant equity related barriers in order to produce better outcomes for the whole society.

\section{Introduction}

COVID-19 is an infectious disease spread by the novel severe acute respiratory syndrome coronavirus 2 (SARSCoV-2), that first reported in Wuhan, China in 2019 [1]. At the start of the pandemic, SARS-CoV-2 was initially thought to spread mainly through close person to person contact because of production of respiratory droplets formed through a sneeze or cough of an infected person. Later evidence demonstrates that the virus also infects through airborne transmission routes when an infected person 'exhales, speaks, shouts, sings, sneezes, or coughs' [2]. SARS-CoV-2 viral particles range from larger respiratory droplets to smaller aerosols [3], making the wearing of high quality and well-fitting masks indoors of particular importance in reducing transmission among the public, and the wearing of additional protective equipment important in reducing transmission among frontline healthcare staff [2]. As of January 5th 2021, 86.2 million cases of COVID-19 have been identified across 218 countries and territories resulting in 1.87 million deaths across the globe [4]. Among the reported cases, 20,551,680 confirmed cases and 349,890 deaths were reported in the USA and (at the time of writing, January 2021) it has become the country with the greatest number of infection and deaths due to COVID-19 [4]. Contrary to US, countries like New Zealand and Vietnam reported 2181 and 1494 cases of COVID-19 resulting into 25 and 35 deaths only respectively [4].

This dire situation demands that everyone has a fair and just opportunity to be as healthy as possible but there is increasing evidence that COVID-19 has unmasked the true magnitude of health inequity worldwide. For example, in US, American Indians or Alaskan natives, African Americans and Hispanic or Latino people have 1.8 times, 1.4 times and 1.7 times higher rate of COVID-19 cases; have 4.0 times, 3.7 times and 4.1 times higher rate of COVID-19 related hospitalizations and 2.6 times, 2.8 times and 2.8 times higher rate of COVID-19 related deaths respectively when compared to their Caucasian counterparts [5]. In addition, elderly people [6], healthcare and frontline workers [7] are at an elevated risk of acquiring COVID-19 and developing severe COVID-19 related outcomes. Thus, to achieve health equity, healthcare policies around COVID-19 should ideally address these inequities so that everyone has a fair opportunity to be as healthy as possible, and the whole society benefits.
Policies and guidance for containing the infection and reducing the COVID-19 related deaths are complex and rapidly evolving. Since no pharmaceutical agents were known to be safe and effective at preventing or treating COVID-19 until recently, only non-pharmaceutical interventions were relied upon for reducing the burden of COVID-19 during the first wave(s) of the pandemic in 2020 [8-11]. These measures aimed to reduce disease transmission both locally and globally and included bans on public gatherings, compulsory stay-at-home policies, mandating closures of schools and nonessential businesses, face mask ordinances, quarantine and cordon sanitaire, among others. The effectiveness of these interventions to reduce COVID-19 transmission has been demonstrated [8-11], however the extent to which health inequity factors were considered in these policies is unknown.

Thus, the aim of this study is to measure the extent to which national, regional, institutional and organizational policies reflect equity considerations by focusing on the global policy landscape around wearing masks and personal protection equipment (PPE). Masks/PPE policies were chosen as area of target as these policies affect more people when compared to other interventional policies such as school closure policies, stay at home policies etc. Equity would be assessed using previously developed Cochrane PROGRESS-Plus equity framework. PROGRESS-plus defines the characteristics that stratify health opportunities and outcomes that can mark inequalities. Current masking/PPE policies implemented across world would ideally be expected to reflect equity considerations in order to effectively manage the spread of the disease and to reduce adverse outcomes, although the extent to which this is the case is uncertain. For example, we may expect equity of access to masks/PPE to be considered when policy-makers are designing policies around the need to wear a mask, or for equity to be considered when undertaking health promotion activities in promoting the importance of mask wearing. The understanding of health equity consideration in masking/PPE policies across globe to contain COVID-19 using PROGRESS-Plus framework will help to achieve a better and more sustainable future for all past the barrier of inequity.

\section{Methods}

This systematic review was done in accordance with Preferred Reporting Items for Systematic Reviews and 
Meta-Analyses (PRISMA) guidelines [12-19] (Table S1), following a predetermined published protocol (PROSPERO registration: CRD42021231497).

\section{Search strategy and data sources}

We performed a comprehensive search in six electronic databases - PubMed, EMBASE, CINAHL, ERIC, ASSIA and Psycinfo. The search strategy was based on a broad combined search string for COVID-19 and 'masks or PPE'(Table S2). The searches were conducted to retrieve potentially relevant publications from January 1st, 2020 to July 1st, 2020. Additional literature was identified by searching the reference list of the identified eligible documents.

\section{Inclusion criteria}

All identified documents were evaluated for the inclusion based on the following criteria: (1) documents should be related to COVID-19 and (2) documents should have masks or PPE as an intervention/strategy to mitigate COVID-19. Selection criteria were not limited to any specific kind of study design or type of publication thus allowing reviews, policy documents, or research briefs to be included in the systematic review. Systematic reviews focusing on a number of policies were excluded to decrease repetition among the included documents. Selection criteria were not limited to any specific language thus minimizing language bias. Two reviewers ( $\mathrm{AC}$ and $\mathrm{AK}$ ) independently undertook the screening of the records (by title and/or abstract) for eligibility and a third reviewer (NC) mediated if contradiction to arrive at an accord occurred. Full text of eligible papers after the first screening was reviewed to confirm that the articles met the inclusion and exclusion criteria. Similar to title/abstract screening, full text screening was also done by two reviewers independently and a third reviewer mediated if contradiction of an accord occurred.

\section{Data extraction}

A customized data extraction sheet was constructed to extract relevant data from all documents meeting our inclusion criteria. The data abstracted included: author(s), publication year, the geographical location of data collection, study design, setting, target population, implementation level of policy, equity incorporation, equity component, strength of evidence and key findings. Similar to the screening process, data extraction was conducted by two reviewers (AC and $\mathrm{AK}$ ) and any contradiction was resolved by a third reviewer (NC).

\section{Assessment of incorporation of equity}

To assess the extent of incorporation of equity in policies, we utilized a guidance framework known as
'PROGRESS-Plus' [20, 21]. This assessment was conducted in order to analyze the extent to which equity has been incorporated in PPE or masking policies and implementation of these policies around the globe. PROGRESS-plus equity framework is aimed at warranting the consideration of various health inequity inducing factors such as place of residence, race/ethnicity, occupation, gender, religion, education, socioeconomic status and personal characteristics when devising policies and/ or guidelines. Additional details about the framework can be found elsewhere [20, 21]. The data from included documents were analyzed to determine whether a study has considered equity component. If the included policy had any of the above-mentioned PROGRESS-Plus components it was determined that the study had incorporated an equity component. Where a measure was classifiable under more than one PROGRESS-Plus factor (e.g. an indicator of employment status is relevant to 'occupation' but also to 'socio-economic status' (SES)), we included it under the factor deemed more appropriate. It is important to note that utilization of PROGRESS-plus framework for this research is context specific and findings are limited to COVID-19 for most part. For instance, population types such as healthcare workers, essential workers are not usually considered vulnerable in society but in the context of COVID-19, increased risk of transmission of COVID-19 puts them at a disadvantage compared to the general population. Thus, findings of the research work should be interpreted within aforementioned scope.

Second, the provision and strength of the rationale to support inclusion of "PROGRESS-plus" factor in a policy was analyzed. The aim of this analysis was to ascertain whether policies have included an equity component following the empirical evidence or not. The documents were divided into two groups: explicit rationale or implicit rationale. If a study/policy provided the empirical evidence for inclusion of PROGRESS-plus component, the study was deemed to have an 'explicit rationale'. The study/policy was deemed to have an 'implicit rationale' if no empirical evidence was provided for the inclusion of PROGRESS-plus component.

Third, "indication level of equity" in documents was assessed. The aim of this analysis was to ascertain whether "equitable health" was a primary factor while framing the policies (defined as high level) or documents were focused on a certain group or subpopulation thus having "equitable health" as a latent factor (defined as low level). The major difference between these two categories is that 'high level' documents acknowledge 'health equity' related issues, as opposed to 'low level' documents which fail to mention them. For example, if a study/policy was targeted at use of face masks among healthcare workers without any mention of 'equity', 
'inequity', 'health disparities' in aims, objectives or discussion, it was deemed to be 'low level'. On the contrary if a study/policy was targeted at use of face masks among healthcare workers with the mention of 'equity', 'inequity', 'health disparities' in aims, objectives or discussion, it was deemed to be 'high level'.

\section{Data analysis}

A narrative synthesis of data was conducted as most of the included documents were policies and lacked statistical results. We presented the data in the two distinct sections. The first section aimed at outlining the included policies in the review and second section aimed at explaining the equity component in the eligible documents. The results are presented in a descriptive manner using frequencies, percentages and pie charts. EPPIreviewer [22] was utilized for the management and analysis of the data . In addition, due to subjective nature of the extracted policy documents, no 'strength of evidence' analysis was performed.

\section{Results}

The search strategy yielded 2177 articles that were focused on COVID-19. Out of these 2177 articles $125 \mathrm{du}$ plicates were removed. Of the remaining 2051 articles only 191 met the inclusion criteria and were retrieved to be reviewed in full-text. In addition, 42 policy documents retrieved from references of these included articles were added to be reviewed in full text. During the full-text screening, further 21 articles were excluded due to following reasons; duplicate $(n=6)$, and irrelevant/ non mask/PPE policy $(n=15)$. This resulted in a total of 212 [23-234] relevant articles to be included in this systematic review (Fig. 1). The screening yielded two types of documents: original policies and policy recommendations. Original policies were the documents issued by government agencies such as $\mathrm{CDC}$, WHO or alike

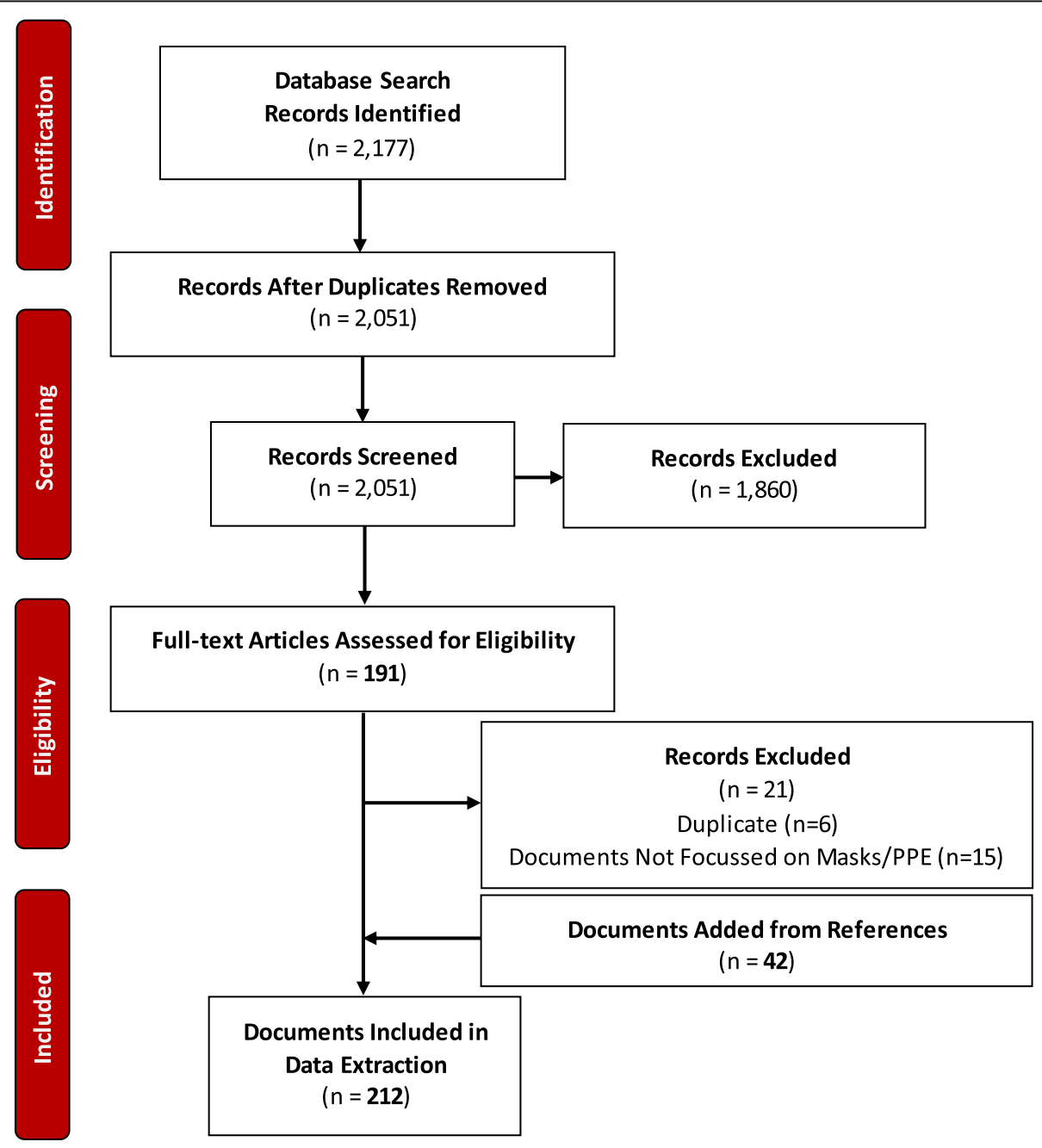

Fig. 1 PRISMA Flow for Selection of the Included Policy Documents 
whereas policy recommendations consisted of documents that were not policies themselves but contained different recommendations for the policy. Both original policies and policy recommendations will be referred to as "policy documents" from here on in the review.

\section{General study characteristics}

General characteristics of the included policy documents are summarized in Table 1. Masks/PPE as a mitigation strategy against COVID-19 was implemented across different regions ranging from USA to Australia to Russia (Table 1 and Fig. 2). There were no policy documents identified from Eastern Europe, Africa and Middle Eastern regions in this review. There were 29 policy documents $[25,34,41,59,75,125,126,133,134,140,141$, $146,155,157,166,177,178,208-219]$ that were not targeted towards a specific nation or region but were global in nature.

The origin/target of policy documents was analyzed on an income level scale (Table 1) as a growing body of literature suggests that there is significant heterogeneity, both in the direction and magnitude, of association between factors such as socioeconomic status, income inequality and health outcomes. Most policy documents were from high income countries (HIC) such as USA, Italy, Canada and UK. Specifically, 136 policy documents (64.15\%) were from HIC [26, 28-33, 37-40, 42-46, 48$58,60,61,63,71-74,76,77,79-82,85-94,99-107,110$, $112,113,116,117,119,121-124,127,129,130,132$, 135, 137-139, 143-145, 147-154, 156, 158, 159, 161, 163-165, 167-172, 174-176, 179-182, 184, 185, 188$204,206,207,220,222,223,226,228,229,233], 39$ policy documents $(18.40 \%)$ were from lower middle income countries (LMIC) [23, 24, 27, 35, 36, 47, 62, 64, 65, 67$70,78,83,84,108,111,114,115,118,128,136,142$, $160,162,173,183,186,187,205,221,224,225,227$, 230-232, 234] and 37 policy documents (17.45\%) were from HIC and LMIC $[25,34,41,59,66,75,95-98,109$, $120,125,126,131,133,134,140,141,146,155,157$, 166, 177, 178, 208-219] (Table 1).

Mask/PPE policy documents were analyzed for the scale upon which they were implemented (Table 1). The scale was divided into categories: institutional, national and global. Institutional policies were defined as the strategies that were implemented at a unit/institution level such as an ophthalmology center or were targeted towards a specific group that work at an institutional level such as an ophthalmologist. National policies were defined as the strategies that were implemented or intended to be implemented at a national level and included all the population of that nation. Policies from country specific agencies such as CDC, Ministero della Salute etc. were considered national policies. Global policies were defined as the policies that were implemented or intended to be implemented at global level and included everyone across globe. Policies from WHO and any other international agencies were included in this category. Our analysis found that most of the policy documents were implemented at an institutional level. Specifically, 148 policy documents (69.81\%) were implemented at institutional level $[25,27-29,31,32$, $34-38,40,42-46,48,49,51,53,58,61-66,71,73,74$, $76-78,80-82,85,86,88-91,93,96,99-110,112-115$, $117,120-126,128,130-139,142-153,155-164,166-$ $168,171,173-184,186,188-190,192,193,197,199$ 204, 206, 207, 210, 211, 213, 220-223, 225-228, 230, 231, 233, 234] whereas 42 policy documents (19.81\%) were implemented at national level $[23,24,26,30,33$, $39,47,50,52,55-57,67-70,72,79,83,84,87,92,94$, $97,98,111,119,129,154,165,169,170,187,191,194-$ $196,198,205,224,229,232]$ and only 22 policy documents $(10.38 \%)$ were implemented at the global level $[41,54,59,60,75,95,116,118,127,140,141,172,185$, 208, 209, 212, 214-219] (Table 1).

In addition, the target population for the policy documents was also assessed (Table 1). Specifically, 141 policy documents (66.51\%) were targeted towards healthcare workers $[23,25-28,30,32,35-42,44-49,51$, $53,54,57,60-66,70-73,76-80,83,86-88,90,91,93$, 96, 98, 99, 101-105, 107-110, 112, 113, 115-117, 119$127,130,133-136,138,139,142-150,152,155-164$, 166, 167, 169-171, 173, 174, 176-181, 183, 186-190, 193, 194, 197-201, 203, 204, 206, 218, 220-223, 225, $228,230,231,233,234]$; 5 policy documents (2.36\%) were targeted towards other workers (mortuary workers, transportation workers, essential workers etc.) [67, 68, 92, 185, 202]; 6 policy documents $(2.83 \%)$ were targeted towards patients across different disease groups [55, 56, $94,100,132,217] ; 30$ policy documents (14.15\%) were targeted for the general population $[24,33,50,52,59$, $75,84,89,95,111,114,118,129,140,141,154,165$, 172, 191, 196, 205, 208, 209, 212, 214-216, 224, 229, 232 ] and 30 policy documents $(14.15 \%)$ had multiple defined target groups $[29,31,34,43,58,69,74,81,82,85$, 97, 106, 128, 131, 137, 151, 153, 168, 175, 182, 184, 192, 195, 207, 210, 211, 213, 219, 226, 227] (Table 1). Examples of policy documents having multiple target groups were policy documents targeting both patients and healthcare workers; policy documents targeting frontline healthcare workers and hospital administrators and policy documents targeting healthcare workers, staff of mortuaries and public health officials (Table 1).

\section{Equity incorporation}

Out of 212 policy documents, 190 policy documents (89.62\%) included at least one PROGRESS-plus component $[23,25-49,51-54,56-83,85-88,90-93,96-99$, 101-117, 119-128, 130, 131, 133-139, 142-164, 166- 
Table 1 Characteristics of The Included Policy Documents

\begin{tabular}{|c|c|c|c|c|c|}
\hline Author and Year & Title & Country & $\begin{array}{l}\text { HIC/ } \\
\text { LMIC }\end{array}$ & Implementation & Target \\
\hline Abramowicz J S [25] & $\begin{array}{l}\text { ISUOG Safety Committee Position Statement on Use } \\
\text { Of Personal Protective Equipment And Hazard } \\
\text { Mitigation In Relation To Sars-Cov-2 For Practitioners } \\
\text { Undertaking Obstetric And Gynaecological } \\
\text { Ultrasound }\end{array}$ & Global & $\begin{array}{l}\text { HIC } \\
\text { and } \\
\text { LMIC }\end{array}$ & Institutional & Healthcare Workers \\
\hline Ağalar C [27] & $\begin{array}{l}\text { Protective Measures for Covid-19 For Healthcare } \\
\text { Providers and Laboratory Personnel }\end{array}$ & Turkey & LMIC & Institutional & Healthcare Workers \\
\hline Amatya S [28] & $\begin{array}{l}\text { Management of New-borns Exposed To Mothers } \\
\text { With Confirmed Or Suspected Covid-19 }\end{array}$ & USA & $\mathrm{HIC}$ & Institutional & Healthcare Workers \\
\hline $\begin{array}{l}\text { American Academy of } \\
\text { Ophthalmology [29] }\end{array}$ & Important coronavirus updates for ophthalmologists & USA & $\mathrm{HIC}$ & Institutional & $\begin{array}{l}\text { Patients and healthcare } \\
\text { workers }\end{array}$ \\
\hline $\begin{array}{l}\text { American Academy of } \\
\text { Paediatrics [31] }\end{array}$ & $\begin{array}{l}\text { Initial guidance: Management of infants born to } \\
\text { mothers with COVID-19 }\end{array}$ & USA & $\mathrm{HIC}$ & Institutional & $\begin{array}{l}\text { Patients and healthcare } \\
\text { workers }\end{array}$ \\
\hline $\begin{array}{l}\text { American College of } \\
\text { Cardiology [32] }\end{array}$ & $\begin{array}{l}\text { Catheterization Laboratory Considerations During } \\
\text { the Coronavirus (COVID-19) Pandemic: From the } \\
\text { ACC's Interventional Council and SCAl }\end{array}$ & USA & $\mathrm{HIC}$ & Institutional & Healthcare Workers \\
\hline $\begin{array}{l}\text { American Geriatrics } \\
\text { Society [33] }\end{array}$ & $\begin{array}{l}\text { American Geriatrics Society (AGS) Policy Brief: } \\
\text { COVID-19 and Assisted Living Facilities }\end{array}$ & USA & $\mathrm{HIC}$ & National & Population Wide \\
\hline AOCMF [34] & $\begin{array}{l}\text { Recommendations on best practices for } \\
\text { Maxillofacial Procedures during COVID } 19 \text { Pandemic }\end{array}$ & Global & $\begin{array}{l}\text { HIC } \\
\text { and } \\
\text { LMIC }\end{array}$ & Institutional & $\begin{array}{l}\text { Patients and healthcare } \\
\text { workers }\end{array}$ \\
\hline Ashari M A [35] & $\begin{array}{l}\text { Strategies for radiology departments in handling } \\
\text { the COVID-19 pandemic }\end{array}$ & Malaysia & LMIC & Institutional & Healthcare Workers \\
\hline Ayan A [36] & $\begin{array}{l}\text { Guide for nuclear medicine applications during the } \\
\text { covid-19 outbreak }\end{array}$ & Turkey & LMIC & Institutional & Healthcare Workers \\
\hline Bann D V [37] & $\begin{array}{l}\text { Impact of coronavirus (COVID-19) on } \\
\text { otolaryngologic surgery: Brief commentary }\end{array}$ & USA & $\mathrm{HIC}$ & Institutional & Healthcare Workers \\
\hline Bann Darrin V [38] & $\begin{array}{l}\text { Best Practice Recommendations for Pediatric } \\
\text { Otolaryngology during the COVID-19 Pandemic }\end{array}$ & USA & $\mathrm{HIC}$ & Institutional & Healthcare Workers \\
\hline Bein B [39] & $\begin{array}{l}\text { SARS-CoV-2/COVID-19: Evidence-Based Recommen- } \\
\text { dations on Diagnosis and Therapy }\end{array}$ & Germany & $\mathrm{HIC}$ & National & Healthcare Workers \\
\hline Bianco F [40] & $\begin{array}{l}\text { Preventing transmission among operating room } \\
\text { staff during COVID-19 pandemic: the role of the } \\
\text { Aerosol Box and other personal protective } \\
\text { equipment }\end{array}$ & Italy & $\mathrm{HIC}$ & Institutional & Healthcare Workers \\
\hline Bikson M [41] & $\begin{array}{l}\text { Guidelines for TMS/tES clinical services and research } \\
\text { through the COVID-19 pandemi }\end{array}$ & Global & $\begin{array}{l}\text { HIC } \\
\text { and } \\
\text { LMIC }\end{array}$ & Global & Healthcare Workers \\
\hline Boccalatte L A [42] & $\begin{array}{l}\text { Brief guideline for the prevention of COVID-19 infec- } \\
\text { tion in head and neck and otolaryngology surgeons }\end{array}$ & Argentina & $\mathrm{HIC}$ & Institutional & Healthcare Workers \\
\hline $\begin{array}{l}\text { National Health } \\
\text { Commission of the } \\
\text { People's Republic of } \\
\text { China [23] }\end{array}$ & $\begin{array}{l}\text { Diagnosis and Treatment Protocol for Novel } \\
\text { Coronavirus Pneumonia }\end{array}$ & China & LMIC & National & Healthcare Workers \\
\hline CAG [43] & $\begin{array}{l}\text { COVID-19: Advice from the Canadian Association of } \\
\text { Gastroenterology for Endoscopy Facilities }\end{array}$ & Canada & $\mathrm{HIC}$ & Institutional & $\begin{array}{l}\text { Patients and healthcare } \\
\text { workers }\end{array}$ \\
\hline Capanna F [45] & $\begin{array}{l}\text { Preparing An Obstetric Unit In The Heart Of The } \\
\text { Epidemic Strike Of Covid-19: Quick Reorganization } \\
\text { Tips }\end{array}$ & $\begin{array}{l}\text { Switzerland, } \\
\text { Spain, Russia, } \\
\text { Austria, Italy }\end{array}$ & $\mathrm{HIC}$ & Institutional & Healthcare Workers \\
\hline Cardinale F [46] & $\begin{array}{l}\text { Consensus Statement Of The Italian Society Of } \\
\text { Pediatric Allergy And Immunology For The } \\
\text { Pragmatic Management Of Children And } \\
\text { Adolescents With Allergic Or Immunological } \\
\text { Diseases During The Covid-19 Pandemic }\end{array}$ & Italy & $\mathrm{HIC}$ & Institutional & Healthcare Workers \\
\hline Carneiro A [47] & $\begin{array}{l}\text { Impact of the COVID-19 Pandemic on the Urolo- } \\
\text { gist's clinical practice in Brazil: a management }\end{array}$ & Brazil & LMIC & National & Healthcare Workers \\
\hline
\end{tabular}


Table 1 Characteristics of The Included Policy Documents (Continued)

\begin{tabular}{|c|c|c|c|c|c|}
\hline Author and Year & Title & Country & $\begin{array}{l}\text { HIC/ } \\
\text { LMIC }\end{array}$ & Implementation & Target \\
\hline & $\begin{array}{l}\text { guideline proposal for low- and middle-income } \\
\text { countries during the crisis period }\end{array}$ & & & & \\
\hline Casiraghi A [48] & $\begin{array}{l}\text { Operational Strategies of A Trauma Hub In Early } \\
\text { Coronavirus Disease } 2019 \text { Pandemic }\end{array}$ & Italy & HIC & Institutional & Healthcare Workers \\
\hline Castelnuovo P [49] & $\begin{array}{l}\text { Skull Base Surgery During the Covid-19 Pandemic: } \\
\text { The Italian Skull Base Society Recommendations }\end{array}$ & Italy & HIC & Institutional & Healthcare Workers \\
\hline CDC [50] & $\begin{array}{l}\text { Coronavirus Disease } 2019 \text { (COVID-19). Frequently } \\
\text { Asked Questions about Personal Protective } \\
\text { Equipment. }\end{array}$ & USA & HIC & National & Population Wide \\
\hline CDC [51] & $\begin{array}{l}\text { Use Personal Protective Equipment (PPE) When } \\
\text { Caring for Patients with Confirmed or Suspected } \\
\text { COVID-19 }\end{array}$ & USA & $\mathrm{HIC}$ & Institutional & Healthcare Workers \\
\hline CDC [52] & Use of Masks to Help Slow the Spread of COVID-19 & USA & HIC & National & Population Wide \\
\hline CDC [53] & $\begin{array}{l}\text { Criteria for Return to Work for Healthcare Personnel } \\
\text { with SARS-CoV-2 Infection (Interim Guidance) }\end{array}$ & USA & HIC & Institutional & Healthcare Workers \\
\hline CDC [54] & $\begin{array}{l}\text { Interim Infection Prevention and Control } \\
\text { Recommendations for Healthcare Personnel During } \\
\text { the Coronavirus Disease } 2019 \text { (COVID-19) Pandemic }\end{array}$ & USA & HIC & Global & Healthcare Workers \\
\hline CDC [55] & Standard Precautions for All Patient Care & USA & HIC & National & Patients \\
\hline CDC [56] & $\begin{array}{l}\text { Interim Clinical Guidance for Management of } \\
\text { Patients with Confirmed Coronavirus Disease } \\
\text { (COVID-19) }\end{array}$ & USA & HIC & National & Patients \\
\hline CDC [57] & $\begin{array}{l}\text { Interim Guidance on Management of Coronavirus } \\
\text { Disease } 2019 \text { (COVID-19) in Correctional and } \\
\text { Detention Facilities }\end{array}$ & USA & $\mathrm{HIC}$ & National & Healthcare Workers \\
\hline Chahar P [58] & $\begin{array}{l}\text { Airway Management Considerations In Patients } \\
\text { With Covid-19 }\end{array}$ & USA & HIC & Institutional & $\begin{array}{l}\text { Patients and healthcare } \\
\text { workers }\end{array}$ \\
\hline Chan T K [59] & $\begin{array}{l}\text { Universal Masking For Covid-19: Evidence, Ethics } \\
\text { And Recommendations }\end{array}$ & Global & $\begin{array}{l}\text { HIC } \\
\text { and } \\
\text { LMIC }\end{array}$ & Global & Population Wide \\
\hline Chandra A [60] & $\begin{array}{l}\text { Personal protective equipment (PPE) for vitreoretinal } \\
\text { surgery during COVID-19 }\end{array}$ & UK & $\mathrm{HIC}$ & Global & Healthcare Workers \\
\hline Chavez S [61] & $\begin{array}{l}\text { Coronavirus Disease (Covid-19): A Primer For } \\
\text { Emergency Physicians }\end{array}$ & USA & HIC & Institutional & Healthcare Workers \\
\hline Chawla D [62] & $\begin{array}{l}\text { Perinatal-Neonatal Management Of Covid-19 Infec- } \\
\text { tion - Guidelines Of The Federation Of Obstetric } \\
\text { And Gynaecological Societies Of India (FOGSI), Na- } \\
\text { tional Neonatology Forum Of India (NNF), And In- } \\
\text { dian Academy Of Paediatrics (IAP) }\end{array}$ & India & LMIC & Institutional & Healthcare Workers \\
\hline Chen W [64] & $\begin{array}{l}\text { To Protect Healthcare Workers Better, To Save More } \\
\text { Lives }\end{array}$ & China & LMIC & Institutional & Healthcare Workers \\
\hline Chen X C [65] & $\begin{array}{l}\text { Preventive and Control Measures for the } \\
\text { Coronavirus Pandemic in Clinical Dentistry }\end{array}$ & China & LMIC & Institutional & Healthcare Workers \\
\hline Chersich M F [66] & $\begin{array}{l}\text { Covid-19 In Africa: Care And Protection For } \\
\text { Frontline Healthcare Workers }\end{array}$ & Africa & $\begin{array}{l}\text { HIC } \\
\text { and } \\
\text { LMIC }\end{array}$ & Institutional & Healthcare Workers \\
\hline Ciavattini A [71] & $\begin{array}{l}\text { Expert Consensus From The Italian Society For } \\
\text { Colposcopy And Cervico-Vaginal Pathology (SICPCV) } \\
\text { For Colposcopy And Outpatient Surgery Of The } \\
\text { Lower Genital Tract During The Covid-19 Pandemic }\end{array}$ & Italy & $\mathrm{HIC}$ & Institutional & Healthcare Workers \\
\hline CMS [72] & $\begin{array}{l}\text { CMS Issues Recommendations to Re-Open Health } \\
\text { Care Systems in Areas with Low Incidence of } \\
\text { COVID-19 }\end{array}$ & USA & HIC & National & Healthcare Workers \\
\hline Coccolini Federico [73] & Surgery in COVID-19 patients: operational directives & Italy & HIC & Institutional & Healthcare Workers \\
\hline Communicable Disease & Novel Coronavirus 2019 (2019-nCoV) Infection: Part & Australia & $\mathrm{HIC}$ & National & Patients and healthcare \\
\hline
\end{tabular}


Table 1 Characteristics of The Included Policy Documents (Continued)

\begin{tabular}{|c|c|c|c|c|c|}
\hline Author and Year & Title & Country & $\begin{array}{l}\text { HIC/ } \\
\text { LMIC }\end{array}$ & Implementation & Target \\
\hline Network Australia [195] & $\begin{array}{l}\text { II - Respiratory Support in the Pediatric Intensive } \\
\text { Care Unit in Resource-limited Settings }\end{array}$ & & & & workers \\
\hline Copland M [74] & $\begin{array}{l}\text { Canadian Society Of Nephrology Covid-19 Rapid Re- } \\
\text { sponse Team Home Dialysis Recommendations }\end{array}$ & Canada & $\mathrm{HIC}$ & Institutional & $\begin{array}{l}\text { Patients and healthcare } \\
\text { workers }\end{array}$ \\
\hline Corburn J [75] & $\begin{array}{l}\text { Slum Health: Arresting COVID-19 and Improving } \\
\text { Well-Being in Urban Informal Settlements }\end{array}$ & Global & $\begin{array}{l}\text { HIC } \\
\text { and } \\
\text { LMIC }\end{array}$ & Global & Population Wide \\
\hline Couloigner V [76] & Covid-19 And ENT Surgery & France & $\mathrm{HIC}$ & Institutional & Healthcare Workers \\
\hline Crosby D L [77] & $\begin{array}{l}\text { Evidence-Based Guidelines for Management of } \\
\text { Head and Neck Mucosal Malignancies during the } \\
\text { COVID-19 Pandemic }\end{array}$ & USA & $\mathrm{HIC}$ & Institutional & Healthcare Workers \\
\hline Cui C [78] & $\begin{array}{l}\text { Approaching Otolaryngology Patients During the } \\
\text { COVID-19 Pandemic }\end{array}$ & China & LMIC & Institutional & Healthcare Workers \\
\hline Curigliano G [79] & $\begin{array}{l}\text { How To Guarantee The Best Of Care To Patients } \\
\text { With Cancer During The Covid-19 Epidemic: The } \\
\text { Italian Experience }\end{array}$ & Italy & $\mathrm{HIC}$ & National & Healthcare Workers \\
\hline D'Aguanno V [80] & $\begin{array}{l}\text { Clinical Recommendations for Epistaxis } \\
\text { Management During the COVID-19 Pandemic }\end{array}$ & Italy & $\mathrm{HIC}$ & Institutional & Healthcare Workers \\
\hline Davenport M S [81] & $\begin{array}{l}\text { ACR Statement On Safe Resumption Of Routine } \\
\text { Radiology Care During The Coronavirus Disease } \\
2019 \text { (Covid-19) Pandemic }\end{array}$ & USA & $\mathrm{HIC}$ & Institutional & $\begin{array}{l}\text { Patients and healthcare } \\
\text { workers }\end{array}$ \\
\hline Day A T [82] & $\begin{array}{l}\text { Head And Neck Oncology During The Covid-19 } \\
\text { Pandemic: Reconsidering Traditional Treatment Par- } \\
\text { adigms In Light Of New Surgical And Other Multi- } \\
\text { level Risks }\end{array}$ & USA & $\mathrm{HIC}$ & Institutional & $\begin{array}{l}\text { Patients and healthcare } \\
\text { workers }\end{array}$ \\
\hline $\begin{array}{l}\text { Deepthi Ramamurthy } \\
\text { [83] }\end{array}$ & $\begin{array}{l}\text { Personal Protective Equipments (PPE) -- } \\
\text { Prerequisites, Rationale and Challenges during } \\
\text { COVID } 19 \text { Pandemic }\end{array}$ & India & LMIC & National & Healthcare Workers \\
\hline Demirbilek Y [84] & $\begin{array}{l}\text { Covid-19 Control, Example Of Ministry Of Health Of } \\
\text { Turkey }\end{array}$ & Turkey & LMIC & National & Population Wide \\
\hline Desai U [85] & $\begin{array}{l}\text { Guidance For Resumption Of Routine } \\
\text { Electrodiagnostic Testing During The Covid-19 } \\
\text { Pandemic }\end{array}$ & USA & $\mathrm{HIC}$ & Institutional & $\begin{array}{l}\text { Patients and healthcare } \\
\text { workers }\end{array}$ \\
\hline DeSerres J J [86] & $\begin{array}{l}\text { Best Practice Guidelines For The Management Of } \\
\text { Acute Craniomaxillofacial Trauma During The Covid- } \\
19 \text { Pandemic }\end{array}$ & Canada & $\mathrm{HIC}$ & Institutional & Healthcare Workers \\
\hline Dexter F [88] & $\begin{array}{l}\text { Perioperative COVID-19 Defense: An Evidence-Based } \\
\text { Approach for Optimization of Infection Control and } \\
\text { Operating Room Management }\end{array}$ & USA & $\mathrm{HIC}$ & Institutional & Healthcare Workers \\
\hline DGP [87] & $\begin{array}{l}\text { Recommendations for treatment of patients with } \\
\text { COVID-19 from the palliative care perspective V2.0 }\end{array}$ & Germany & $\mathrm{HIC}$ & National & Healthcare Workers \\
\hline Di Saverio [89] & $\begin{array}{l}\text { Coronavirus Pandemic And Colorectal Surgery: } \\
\text { Practical Advice Based On The Italian Experience }\end{array}$ & Italy & $\mathrm{HIC}$ & Institutional & Population Wide \\
\hline Dockery D M [91] & $\begin{array}{l}\text { The Ocular Manifestations And Transmission Of } \\
\text { Covid-19: Recommendations For Prevention }\end{array}$ & USA & $\mathrm{HIC}$ & Institutional & Healthcare Workers \\
\hline Dyal J W [92] & $\begin{array}{l}\text { COVID-19 Among Workers in Meat and Poultry } \\
\text { Processing Facilities - } 19 \text { States, April } 2020\end{array}$ & USA & $\mathrm{HIC}$ & National & Meat/poultry workers \\
\hline Elli L [93] & $\begin{array}{l}\text { Endoscopy During The Covid-19 Outbreak: Experi- } \\
\text { ence And Recommendations From A Single Center } \\
\text { In A High-Incidence Scenario }\end{array}$ & Italy & $\mathrm{HIC}$ & Institutional & Healthcare Workers \\
\hline Esposito S [94] & $\begin{array}{l}\text { To mask or not to mask children to overcome } \\
\text { COVID-19 }\end{array}$ & Italy & $\mathrm{HIC}$ & National & Patients \\
\hline Esposito S [95] & $\begin{array}{l}\text { Universal use of face masks for success against } \\
\text { COVID-19: evidence and implications for prevention } \\
\text { policies }\end{array}$ & Italy \& China & $\begin{array}{l}\text { HIC } \\
\text { and } \\
\text { LMIC }\end{array}$ & Global & Population Wide \\
\hline
\end{tabular}


Table 1 Characteristics of The Included Policy Documents (Continued)

\begin{tabular}{|c|c|c|c|c|c|}
\hline Author and Year & Title & Country & $\begin{array}{l}\mathrm{HIC/} \\
\mathrm{LMIC}\end{array}$ & Implementation & Target \\
\hline $\begin{array}{l}\text { European Centre for } \\
\text { Disease Prevention and } \\
\text { Control [98] }\end{array}$ & $\begin{array}{l}\text { Infection prevention and control and preparedness } \\
\text { for COVID-19 in healthcare settings - fourth update }\end{array}$ & Europe & $\begin{array}{l}\text { HIC } \\
\text { and } \\
\text { LMIC }\end{array}$ & National & Healthcare Workers \\
\hline $\begin{array}{l}\text { European Centre for } \\
\text { Disease Prevention and } \\
\text { Control (ECDC) [96] }\end{array}$ & $\begin{array}{l}\text { Infection Prevention and Control For the Care of } \\
\text { Patients With 2019-nCoV in Healthcare Setting }\end{array}$ & Europe & $\begin{array}{l}\text { HIC } \\
\text { and } \\
\text { LMIC }\end{array}$ & Institutional & Healthcare Workers \\
\hline $\begin{array}{l}\text { European Centre for } \\
\text { Disease Prevention and } \\
\text { Control [97] }\end{array}$ & $\begin{array}{l}\text { Infection prevention and control for the care of } \\
\text { patients with 2019-nCoV in healthcare settings }\end{array}$ & Europe & $\begin{array}{l}\text { HIC } \\
\text { and } \\
\text { LMIC }\end{array}$ & National & $\begin{array}{l}\text { Healthcare Workers and } \\
\text { Hospital Administration }\end{array}$ \\
\hline $\begin{array}{l}\text { Evidence-Based } \\
\text { Medicine Chapter of } \\
\text { China [128] }\end{array}$ & $\begin{array}{l}\text { A rapid advice guideline for the diagnosis and } \\
\text { treatment of } 2019 \text { novel coronavirus ( } 2019-\mathrm{nCov} \text { ) } \\
\text { infected pneumonia (standard version) }\end{array}$ & China & LMIC & Institutional & $\begin{array}{l}\text { Patients and healthcare } \\
\text { workers }\end{array}$ \\
\hline Fananapazir G [99] & $\begin{array}{l}\text { Reorganizing Cross-Sectional Interventional Proce- } \\
\text { dures Practice During the Coronavirus Disease } \\
\text { (COVID-19) Pandemic }\end{array}$ & USA & $\mathrm{HIC}$ & Institutional & Healthcare Workers \\
\hline Fawley N [100] & Procedural sedation in the COVID-19 era & USA & $\mathrm{HIC}$ & Institutional & Patients \\
\hline Fillingham Y A [101] & $\begin{array}{l}\text { Personal Protective Equipment: Current Best } \\
\text { Practices for Orthopedic Teams }\end{array}$ & USA & $\mathrm{HIC}$ & Institutional & Healthcare Workers \\
\hline Forrester J D [102] & $\begin{array}{l}\text { Precautions for Operating Room Team Members } \\
\text { During the COVID-19 Pandemic }\end{array}$ & USA & $\mathrm{HIC}$ & Institutional & Healthcare Workers \\
\hline Francis N [103] & $\begin{array}{l}\text { SAGES and EAES recommendations for minimally } \\
\text { invasive surgery during COVID-19 pandemic }\end{array}$ & $\begin{array}{l}\text { USA, UK, Italy, } \\
\text { Spain }\end{array}$ & $\mathrm{HIC}$ & Institutional & Healthcare Workers \\
\hline Friese C R [104] & $\begin{array}{l}\text { Respiratory Protection Considerations For } \\
\text { Healthcare Workers During The Covid-19 Pandemic }\end{array}$ & USA & $\mathrm{HIC}$ & Institutional & Healthcare Workers \\
\hline Furfaro F [105] & $\begin{array}{l}\text { SFED recommendations for IBD endoscopy during } \\
\text { COVID-19 pandemic: Italian and French experience }\end{array}$ & Italy and France & $\mathrm{HIC}$ & Institutional & Healthcare Workers \\
\hline Gackowski A [106] & $\begin{array}{l}\text { Echocardiography During The Coronavirus Disease } \\
2019 \text { (Covid-19) Pandemic: Expert Opinion Of The } \\
\text { Working Group On Echocardiography Of The Polish } \\
\text { Cardiac Society }\end{array}$ & Poland & $\mathrm{HIC}$ & Institutional & $\begin{array}{l}\text { Patients and healthcare } \\
\text { workers }\end{array}$ \\
\hline Galloro G [107] & $\begin{array}{l}\text { Safety in digestive endoscopy procedures in the } \\
\text { covid era recommendations in progres of the italian } \\
\text { society of digestive endoscopy }\end{array}$ & Italy & $\mathrm{HIC}$ & Institutional & Healthcare Workers \\
\hline Gemicioğlu Bilun [108] & $\begin{array}{l}\text { Turkish Thoracic Society Experts Consensus Report: } \\
\text { Recommendations for Pulmonary Function Tests } \\
\text { During and After COVID } 19 \text { Pandemic }\end{array}$ & Turkey & LMIC & Institutional & Healthcare Workers \\
\hline George M [109] & $\begin{array}{l}\text { Proposal of a timing strategy for cholesteatoma } \\
\text { surgery during the COVID-19 pandemic }\end{array}$ & $\begin{array}{l}\text { Oman, Italy, } \\
\text { India }\end{array}$ & $\begin{array}{l}\text { HIC } \\
\text { and } \\
\text { LMIC }\end{array}$ & Institutional & Healthcare Workers \\
\hline Goh Ken Junyang [110] & $\begin{array}{l}\text { Preparing your intensive care unit for the COVID-19 } \\
\text { pandemic: practical considerations and strategies }\end{array}$ & Singapore & $\mathrm{HIC}$ & Institutional & Healthcare Workers \\
\hline Gorry C [111] & $\begin{array}{l}\text { Covid-19 Case Detection: Cuba'S Active Screening } \\
\text { Approach }\end{array}$ & Cuba & LMIC & National & Population Wide \\
\hline Gosling A F [112] & $\begin{array}{l}\text { Perioperative Considerations for Tracheostomies In } \\
\text { The Era Of Covid-19 }\end{array}$ & USA & $\mathrm{HIC}$ & Institutional & Healthcare Workers \\
\hline $\begin{array}{l}\text { Government of Canada } \\
\text { [113] }\end{array}$ & $\begin{array}{l}\text { Infection prevention and control for COVID-19: Sec- } \\
\text { ond interim guidance for acute healthcare settings }\end{array}$ & Canada & $\mathrm{HIC}$ & Institutional & Healthcare Workers \\
\hline Gupta Arti [114] & $\begin{array}{l}\text { Managing a COVID } 19 \text { patient at different health } \\
\text { care and field level settings }\end{array}$ & India & LMIC & Institutional & Population Wide \\
\hline Gupta P [115] & $\begin{array}{l}\text { Neurosurgery and Neurology Practices during the } \\
\text { Novel COVID-19 Pandemic: A Consensus Statement } \\
\text { from India }\end{array}$ & India & LMIC & Institutional & Healthcare Workers \\
\hline Ha J F [116] & $\begin{array}{l}\text { The covid- } 19 \text { pandemic, personal protective equip- } \\
\text { ment, and respirator: a narrative review }\end{array}$ & Australia & $\mathrm{HIC}$ & Global & Healthcare Workers \\
\hline Haines S [117] & Practical Considerations When Performing & USA & $\mathrm{HIC}$ & Institutional & Healthcare Workers \\
\hline
\end{tabular}


Table 1 Characteristics of The Included Policy Documents (Continued)

\begin{tabular}{|c|c|c|c|c|c|}
\hline Author and Year & Title & Country & $\begin{array}{l}\mathrm{HIC/} \\
\mathrm{LMIC}\end{array}$ & Implementation & Target \\
\hline & $\begin{array}{l}\text { Neurodiagnostic Studies on Patients with COVID-19 } \\
\text { and Other Highly Virulent Diseases }\end{array}$ & & & & \\
\hline Han G [118] & $\begin{array}{l}\text { Possibly Critical Role Of Wearing Masks In General } \\
\text { Population In Controlling Covid-19 }\end{array}$ & China & LMIC & Global & Population Wide \\
\hline $\begin{array}{l}\text { Healthcare Purchasing } \\
\text { News [119] }\end{array}$ & $\begin{array}{l}\text { CDC Updates Recommendations For Healthcare } \\
\text { Supply Of PPE }\end{array}$ & USA & $\mathrm{HIC}$ & National & Healthcare Workers \\
\hline Heldwein F L [120] & $\begin{array}{l}\text { A Systematic Review on Guidelines and } \\
\text { Recommendations for Urology Standard of Care } \\
\text { During the COVID-19 Pandemic }\end{array}$ & UK, USA, China & $\begin{array}{l}\text { HIC } \\
\text { and } \\
\text { LMIC }\end{array}$ & Institutional & Healthcare Workers \\
\hline Higginson Ray [121] & $\begin{array}{l}\text { Paramedic Use Of PPE And Testing During The } \\
\text { COVID-19 Pandemic }\end{array}$ & UK & $\mathrm{HIC}$ & Institutional & Healthcare Workers \\
\hline Higginson Ray [122] & $\begin{array}{l}\text { Personal protective equipment and testing during } \\
\text { the COVID-19 pandemic }\end{array}$ & UK & $\mathrm{HIC}$ & Institutional & Healthcare Workers \\
\hline Hirschmann M T [123] & $\begin{array}{l}\text { COVID-19 coronavirus: recommended personal } \\
\text { protective equipment for the orthopaedic and } \\
\text { trauma surgeon }\end{array}$ & $\begin{array}{l}\text { Austria, } \\
\text { Luxembourg, } \\
\text { Switzerland, } \\
\text { Germany, UK }\end{array}$ & HIC & Institutional & Healthcare Workers \\
\hline Hsieh T Y [124] & $\begin{array}{l}\text { A Guide To Facial Trauma Triage And Precautions In } \\
\text { The Covid-19 Pandemic }\end{array}$ & USA & $\mathrm{HIC}$ & Institutional & Healthcare Workers \\
\hline Hu-Friedy [125] & $\begin{array}{l}\text { Best Practices For Hand Hygiene And Face Mask } \\
\text { Use }\end{array}$ & Global & $\begin{array}{l}\text { HIC } \\
\text { and } \\
\text { LMIC }\end{array}$ & Institutional & Healthcare Workers \\
\hline lacucci M [126] & $\begin{array}{l}\text { Endoscopy In Inflammatory Bowel Diseases During } \\
\text { The Covid-19 Pandemic And Post-Pandemic Period }\end{array}$ & Global & $\begin{array}{l}\text { HIC } \\
\text { and } \\
\text { LMIC }\end{array}$ & Institutional & Healthcare Workers \\
\hline Islam M S [127] & $\begin{array}{l}\text { Examining the current intelligence on COVID-19 } \\
\text { and infection prevention and control strategies in } \\
\text { health settings: A global analysis }\end{array}$ & Australia & HIC & Global & Healthcare Workers \\
\hline Jung F [129] & $\begin{array}{l}\text { How we should respond to the Coronavirus SARS- } \\
\text { CoV-2 outbreak: A German perspective }\end{array}$ & Germany & $\mathrm{HIC}$ & National & Population Wide \\
\hline Kabesch M [130] & $\begin{array}{l}\text { Successful Containment Of Covid-19 Outbreak In A } \\
\text { Large Maternity And Perinatal Center While Con- } \\
\text { tinuing Clinical Service }\end{array}$ & Germany & $\mathrm{HIC}$ & Institutional & Healthcare Workers \\
\hline Kligerman M P [131] & $\begin{array}{l}\text { Managing Head And Neck Cancer Patients With } \\
\text { Tracheostomy Or Laryngectomy During The Covid- } \\
19 \text { Pandemic }\end{array}$ & USA and China & $\begin{array}{l}\text { HIC } \\
\text { and } \\
\text { LMIC }\end{array}$ & Institutional & $\begin{array}{l}\text { Patients and healthcare } \\
\text { workers }\end{array}$ \\
\hline Kluge S [132] & $\begin{array}{l}\text { German recommendations for critically ill patients } \\
\text { with COVID-19 }\end{array}$ & Germany & $\mathrm{HIC}$ & Institutional & Patients \\
\hline Korobelnik J F [133] & $\begin{array}{l}\text { Guidance for anti-VEGF intravitreal injections during } \\
\text { the COVID-19 pandemic }\end{array}$ & Global & $\begin{array}{l}\text { HIC } \\
\text { and } \\
\text { LMIC }\end{array}$ & Institutional & Healthcare Workers \\
\hline Kowalski L P [134] & $\begin{array}{l}\text { Covid-19 Pandemic: Effects And Evidence-Based } \\
\text { Recommendations For Otolaryngology And Head } \\
\text { And Neck Surgery Practice }\end{array}$ & Global & $\begin{array}{l}\text { HIC } \\
\text { and } \\
\text { LMIC }\end{array}$ & Institutional & Healthcare Workers \\
\hline Lammers Marc J. W [135] & $\begin{array}{l}\text { Guidance For Otolaryngology Health Care Workers } \\
\text { Performing Aerosol Generating Medical Procedures } \\
\text { During The Covid-19 Pandemic }\end{array}$ & Canada & $\mathrm{HIC}$ & Institutional & Healthcare Workers \\
\hline Lavinsky J [136] & $\begin{array}{l}\text { An Update On Covid-19 For The Otorhinolaryngolo- } \\
\text { gist - A Brazilian Association Of Otolaryngology } \\
\text { And Cervicofacial Surgery (Aborl-Ccf) Position } \\
\text { Statement }\end{array}$ & Brazil & LMIC & Institutional & Healthcare Workers \\
\hline Leboulanger N [137] & $\begin{array}{l}\text { Covid-19 And Ent Pediatric Otolaryngology During } \\
\text { The Covid-19 Pandemic. Guidelines Of The French } \\
\text { Association Of Pediatric Otorhinolaryngology (Afop) } \\
\text { And French Society Of Otorhinolaryngology (Sforl) }\end{array}$ & France & $\mathrm{HIC}$ & Institutional & $\begin{array}{l}\text { Patients and healthcare } \\
\text { workers }\end{array}$ \\
\hline Lescanne E [139] & Best practice recommendations: ENT consultations & France & $\mathrm{HIC}$ & Institutional & Healthcare Workers \\
\hline
\end{tabular}


Table 1 Characteristics of The Included Policy Documents (Continued)

\begin{tabular}{|c|c|c|c|c|c|}
\hline Author and Year & Title & Country & $\begin{array}{l}\text { HIC/ } \\
\text { LMIC }\end{array}$ & Implementation & Target \\
\hline & during the COVID-19 pandemic & & & & \\
\hline Leung C C [140] & $\begin{array}{l}\text { Mask Wearing To Complement Social Distancing } \\
\text { And Save Lives During Covid-19 }\end{array}$ & Global & $\begin{array}{l}\text { HIC } \\
\text { and } \\
\text { LMIC }\end{array}$ & Global & Population Wide \\
\hline Leung Chi Chiu [141] & $\begin{array}{l}\text { Mass Masking In The Covid-19 Epidemic: People } \\
\text { Need Guidance }\end{array}$ & Global & $\begin{array}{l}\text { HIC } \\
\text { and } \\
\text { LMIC }\end{array}$ & Global & Population Wide \\
\hline Li Zhijie [142] & $\begin{array}{l}\text { How Ophthalmologists should understand and } \\
\text { respond to the current epidemic of novel } \\
\text { coronavirus pneumonia }\end{array}$ & China & LMIC & Institutional & Healthcare Workers \\
\hline Lie S A [143] & $\begin{array}{l}\text { Practical considerations for performing regional } \\
\text { anesthesia: lessons learned from the COVID-19 } \\
\text { pandemic }\end{array}$ & Singapore & $\mathrm{HIC}$ & Institutional & Healthcare Workers \\
\hline Lim L W [144] & $\begin{array}{l}\text { Sustainable Practice Of Ophthalmology During } \\
\text { Covid-19: Challenges And Solutions }\end{array}$ & Singapore & $\mathrm{HIC}$ & Institutional & Healthcare Workers \\
\hline Lockhart S L [145] & $\begin{array}{l}\text { Personal protective equipment (PPE) for both } \\
\text { anesthesiologists and other airway managers: } \\
\text { principles and practice during the COVID-19 } \\
\text { pandemic }\end{array}$ & Canada & $\mathrm{HIC}$ & Institutional & Healthcare Workers \\
\hline Ludovico G [138] & $\begin{array}{l}\text { Hospital care in Departments defined as Covid-free: } \\
\text { A proposal for a safe hospitalization protecting } \\
\text { healthcare professionals and patients not affected } \\
\text { by Covid } 19\end{array}$ & Italy & $\mathrm{HIC}$ & Institutional & Healthcare Workers \\
\hline Maclntyre C Raina [172] & $\begin{array}{l}\text { Community Universal Face Mask Use During The } \\
\text { Covid } 19 \text { Pandemic-From Households To Travellers } \\
\text { And Public Spaces }\end{array}$ & USA & $\mathrm{HIC}$ & Global & Population Wide \\
\hline Matava C T [146] & $\begin{array}{l}\text { Pediatric Airway Management In Covid-19 Patients - } \\
\text { Consensus Guidelines From The Society For } \\
\text { Pediatric Anesthesia'S Pediatric Difficult Intubation } \\
\text { Collaborative And The Canadian Pediatric } \\
\text { Anesthesia Society }\end{array}$ & Global & $\begin{array}{l}\text { HIC } \\
\text { and } \\
\text { LMIC }\end{array}$ & Institutional & Healthcare Workers \\
\hline Mattei A [147] & $\begin{array}{l}\text { Guidelines of clinical practice for the management } \\
\text { of swallowing disorders and recent dysphonia in } \\
\text { the context of the COVID-19 pandemic }\end{array}$ & France & $\mathrm{HIC}$ & Institutional & Healthcare Workers \\
\hline McGrath B A [148] & $\begin{array}{l}\text { Multidisciplinary Guidance For Safe Tracheostomy } \\
\text { Care During The Covid-19 Pandemic: The Nhs Na- } \\
\text { tional Patient Safety Improvement Programme } \\
\text { (Natpatsip) }\end{array}$ & UK & $\mathrm{HIC}$ & Institutional & Healthcare Workers \\
\hline Micali G [149] & $\begin{array}{l}\text { The Italian dermatologic community facing COVID- } \\
19 \text { pandemic: recommendation from the Italian so- } \\
\text { ciety of dermatology and venereology }\end{array}$ & Italy & $\mathrm{HIC}$ & Institutional & Healthcare Workers \\
\hline Milad Abdi [24] & $\begin{array}{l}\text { Coronavirus disease } 2019 \text { (COVID-19) outbreak in } \\
\text { Iran: actions and problems }\end{array}$ & Iran & LMIC & National & Population Wide \\
\hline Mujoomdar A [150] & $\begin{array}{l}\text { The Canadian Association for Interventional } \\
\text { Radiology (CAIR) and Canadian Association of } \\
\text { Radiologists (CAR) Guidelines for Interventional } \\
\text { Radiology Procedures for Patients With Suspected } \\
\text { or Confirmed COVID-19 }\end{array}$ & Canada & $\mathrm{HIC}$ & Institutional & Healthcare Workers \\
\hline Mupparapu Mel [151] & $\begin{array}{l}\text { Dental Practitioners' Role In The Assessment And } \\
\text { Containment Of Coronavirus Disease (Covid-19): } \\
\text { Evolving Recommendations From The Centers For } \\
\text { Disease Control }\end{array}$ & USA & $\mathrm{HIC}$ & Institutional & $\begin{array}{l}\text { Patients and healthcare } \\
\text { workers }\end{array}$ \\
\hline Mytrang H. Do [90] & $\begin{array}{l}\text { Recommendations For Personal Protective } \\
\text { Equipment And Smoke Evacuation For } \\
\text { Dermatologic Surgeries Amid The Covid-19 Crisis }\end{array}$ & USA & $\mathrm{HIC}$ & Institutional & Healthcare Workers \\
\hline $\mathrm{Ng} J J$ [152] & $\begin{array}{l}\text { Experience from a Singapore tertiary hospital with } \\
\text { restructuring a vascular surgery practice in response } \\
\text { to national and institutional policies during the }\end{array}$ & Singapore & $\mathrm{HIC}$ & Institutional & Healthcare Workers \\
\hline
\end{tabular}


Table 1 Characteristics of The Included Policy Documents (Continued)

\begin{tabular}{|c|c|c|c|c|c|}
\hline Author and Year & Title & Country & $\begin{array}{l}\text { HIC/ } \\
\text { LMIC }\end{array}$ & Implementation & Target \\
\hline & COVID-19 pandemic & & & & \\
\hline NICE [153] & COVID-19 rapid guideline: critical care in adults & UK & $\mathrm{HIC}$ & Institutional & $\begin{array}{l}\text { Patients and healthcare } \\
\text { workers }\end{array}$ \\
\hline NICE [154] & $\begin{array}{l}\text { COVID-19 rapid guideline: managing symptoms } \\
\text { (including at the end of life) in the community }\end{array}$ & UK & $\mathrm{HIC}$ & National & Population Wide \\
\hline Nolan J P [155] & $\begin{array}{l}\text { European Resuscitation Council Covid-19 Guidelines } \\
\text { Executive Summary }\end{array}$ & Global & $\begin{array}{l}\text { HIC } \\
\text { and } \\
\text { LMIC }\end{array}$ & Institutional & Healthcare Workers \\
\hline Ortega R [156] & Personal Protective Equipment and Covid-19 & USA & $\mathrm{HIC}$ & Institutional & Healthcare Workers \\
\hline Paez D [157] & $\begin{array}{l}\text { COVID-19 pandemic: guidance for nuclear medicine } \\
\text { departments }\end{array}$ & Global & $\begin{array}{l}\text { HIC } \\
\text { and } \\
\text { LMIC }\end{array}$ & Institutional & Healthcare Workers \\
\hline Palatnik A [158] & $\begin{array}{l}\text { Protecting Labor and Delivery Personnel from } \\
\text { COVID-19 during the Second Stage of Labor }\end{array}$ & USA & $\mathrm{HIC}$ & Institutional & Healthcare Workers \\
\hline Pan Lijun [67] & $\begin{array}{l}\text { Health protection guideline of enterprises during } \\
\text { COVID-19 outbreak }\end{array}$ & China & LMIC & National & Enterprise employees \\
\hline Panesar K [159] & $\begin{array}{l}\text { Evolution Of Covid-19 Guidelines For University Of } \\
\text { Washington Oral And Maxillofacial Surgery Patient } \\
\text { Care }\end{array}$ & USA & $\mathrm{HIC}$ & Institutional & Healthcare Workers \\
\hline Panuganti B A [160] & $\begin{array}{l}\text { Procedural Precautions And Personal Protective } \\
\text { Equipment During Head And Neck Instrumentation } \\
\text { In The Covid-19 Era }\end{array}$ & China & LMIC & Institutional & Healthcare Workers \\
\hline Patel V [161] & $\begin{array}{l}\text { Cardiac Surgery during the COVID-19 Pandemic: } \\
\text { Perioperative Considerations and Triage } \\
\text { Recommendations }\end{array}$ & USA & $\mathrm{HIC}$ & Institutional & Healthcare Workers \\
\hline Patwa A [162] & $\begin{array}{l}\text { All India difficult airway association (AIDAA) } \\
\text { consensus guidelines for airway management in the } \\
\text { operating room during the COVID-19 pandemic }\end{array}$ & India & LMIC & Institutional & Healthcare Workers \\
\hline Peditto M [163] & $\begin{array}{l}\text { Dentistry during the covid-19 epidemic: An italian } \\
\text { workflow for the management of dental practice }\end{array}$ & Italy & $\mathrm{HIC}$ & Institutional & Healthcare Workers \\
\hline $\begin{array}{l}\text { Peraza-Smith George } \\
\text { Byron [164] }\end{array}$ & $\begin{array}{l}\text { Imperative for a Safe and Healthy Workplace for } \\
\text { Nurses }\end{array}$ & USA & $\mathrm{HIC}$ & Institutional & Healthcare Workers \\
\hline Perencevich E N [165] & $\begin{array}{l}\text { Moving Personal Protective Equipment Into The } \\
\text { Community: Face Shields And Containment Of } \\
\text { Covid-19 }\end{array}$ & USA & $\mathrm{HIC}$ & National & Population Wide \\
\hline Perkins G D [166] & $\begin{array}{l}\text { International Liaison Committee On Resuscitation: } \\
\text { Covid-19 Consensus On Science, Treatment Recom- } \\
\text { mendations And Task Force Insights }\end{array}$ & Global & $\begin{array}{l}\text { HIC } \\
\text { and } \\
\text { LMIC }\end{array}$ & Institutional & Healthcare Workers \\
\hline Pezzulla D [167] & $\begin{array}{l}\text { Radiotherapy In Southern Italy At The Time Of } \\
\text { Covid-19: Options For Radiation Oncology Units }\end{array}$ & Italy & $\mathrm{HIC}$ & Institutional & Healthcare Workers \\
\hline $\begin{array}{l}\text { Public Health England } \\
\text { [168] }\end{array}$ & $\begin{array}{l}\text { COVID-19: Infection Prevention and Control } \\
\text { Guidance }\end{array}$ & UK & $\mathrm{HIC}$ & Institutional & $\begin{array}{l}\text { Patients, healthcare } \\
\text { workers and hospital } \\
\text { visitors }\end{array}$ \\
\hline $\begin{array}{l}\text { Public Health England } \\
\text { [169] }\end{array}$ & $\begin{array}{l}\text { COVID-19: management of staff and exposed } \\
\text { patients or residents in health and social care } \\
\text { settings }\end{array}$ & UK & $\mathrm{HIC}$ & National & Healthcare Workers \\
\hline $\begin{array}{l}\text { Public health England } \\
\text { [170] }\end{array}$ & $\begin{array}{l}\text { New recommendations for primary and community } \\
\text { health care providers in England }\end{array}$ & UK & $\mathrm{HIC}$ & National & Healthcare Workers \\
\hline Quah Li Juan Joy [171] & $\begin{array}{l}\text { Reorganising The Emergency Department To } \\
\text { Manage The Covid-19 Outbreak }\end{array}$ & Singapore & $\mathrm{HIC}$ & Institutional & Healthcare Workers \\
\hline Ramos R F [173] & $\begin{array}{l}\text { Recommendations of the Brazilian College of } \\
\text { Surgeons for laparoscopic surgery during the } \\
\text { COVID-19 pandemic }\end{array}$ & Brazil & LMIC & Institutional & Healthcare Workers \\
\hline Randelli P S [174] & $\begin{array}{l}\text { Management Of Orthopaedic And Traumatology } \\
\text { Patients During The Coronavirus Disease (Covid-19) }\end{array}$ & Italy & $\mathrm{HIC}$ & Institutional & Healthcare Workers \\
\hline
\end{tabular}


Table 1 Characteristics of The Included Policy Documents (Continued)

\begin{tabular}{|c|c|c|c|c|c|}
\hline Author and Year & Title & Country & $\begin{array}{l}\text { HIC/ } \\
\text { LMIC }\end{array}$ & Implementation & Target \\
\hline & Pandemic In Northern Italy & & & & \\
\hline Rochelson Burton [175] & $\begin{array}{l}\text { The Care Of Pregnant Women During The Covid-19 } \\
\text { Pandemic - Response Of A Large Health System In } \\
\text { Metropolitan New York }\end{array}$ & USA & $\mathrm{HIC}$ & Institutional & $\begin{array}{l}\text { Patients and healthcare } \\
\text { workers }\end{array}$ \\
\hline Saadi R A [176] & $\begin{array}{l}\text { A Commentary On Safety Precautions For Otologic } \\
\text { Surgery During The Covid-19 Pandemic }\end{array}$ & USA & $\mathrm{HIC}$ & Institutional & Healthcare Workers \\
\hline Saenz L C [177] & $\begin{array}{l}\text { Recommendations For The Organization Of } \\
\text { Electrophysiology And Cardiac Pacing Services } \\
\text { During The Covid-19 Pandemic }\end{array}$ & Global & $\begin{array}{l}\text { HIC } \\
\text { and } \\
\text { LMIC }\end{array}$ & Institutional & Healthcare Workers \\
\hline San-Juan D [178] & $\begin{array}{l}\text { Guidance for clinical neurophysiology examination } \\
\text { throughout the COVID-19 pandemic. Latin American } \\
\text { chapter of the IFCN task force - COVID-19 }\end{array}$ & Global & $\begin{array}{l}\text { HIC } \\
\text { and } \\
\text { LMIC }\end{array}$ & Institutional & Healthcare Workers \\
\hline Say D S [179] & $\begin{array}{l}\text { Risk stratification and personal protective } \\
\text { equipment use in pediatric endoscopy during the } \\
\text { coronavirus disease } 2019 \text { outbreak: A single-center } \\
\text { protocol }\end{array}$ & USA & $\mathrm{HIC}$ & Institutional & Healthcare Workers \\
\hline Sayburn A [180] & $\begin{array}{l}\text { Covid-19: Phe Upgrades Ppe Advice For All Patient } \\
\text { Contacts With Risk Of Infection }\end{array}$ & UK & $\mathrm{HIC}$ & Institutional & Healthcare Workers \\
\hline Schultz P [181] & $\begin{array}{l}\text { French consensus regarding precautions during } \\
\text { tracheostomy and post-tracheostomy care in the } \\
\text { context of COVID-19 pandemic }\end{array}$ & France & $\mathrm{HIC}$ & Institutional & Healthcare Workers \\
\hline Seely J M [182] & $\begin{array}{l}\text { Covid-19: Safe Guidelines For Breast Imaging During } \\
\text { The Pandemic }\end{array}$ & Canada & $\mathrm{HIC}$ & Institutional & $\begin{array}{l}\text { Patients and healthcare } \\
\text { workers }\end{array}$ \\
\hline Sengupta S [183] & $\begin{array}{l}\text { All India Ophthalmological Society - Indian Journal } \\
\text { of Ophthalmology consensus statement on } \\
\text { preferred practices during the COVID-19 pandemic }\end{array}$ & India & LMIC & Institutional & Healthcare Workers \\
\hline Shaker M S [184] & $\begin{array}{l}\text { Covid-19: Pandemic Contingency Planning For The } \\
\text { Allergy And Immunology Clinic }\end{array}$ & $\begin{array}{l}\text { USA and } \\
\text { Canada }\end{array}$ & $\mathrm{HIC}$ & Institutional & $\begin{array}{l}\text { Patients and healthcare } \\
\text { workers }\end{array}$ \\
\hline Sharma Vandana [185] & $\begin{array}{l}\text { Prioritizing vulnerable populations and women on } \\
\text { the frontlines: COVID-19 in humanitarian contexts }\end{array}$ & USA & $\mathrm{HIC}$ & Global & Essential Workers \\
\hline Singh A G [186] & $\begin{array}{l}\text { Navigating the impact of COVID-19 on palliative } \\
\text { care for head and neck cancer }\end{array}$ & India & LMIC & Institutional & Healthcare Workers \\
\hline Singh B [187] & $\begin{array}{l}\text { Indian resuscitation council (IRC) suggested } \\
\text { guidelines for comprehensive cardiopulmonary life } \\
\text { support (CCLS) for suspected or confirmed } \\
\text { coronavirus disease (COVID-19) patient }\end{array}$ & India & LMIC & National & Healthcare Workers \\
\hline Sobel D [188] & $\begin{array}{l}\text { Personal Protective Equipment for Common } \\
\text { Urologic Procedures Before and During the United } \\
\text { States COVID-19 Pandemic: A Single Institution } \\
\text { Study }\end{array}$ & USA & $\mathrm{HIC}$ & Institutional & Healthcare Workers \\
\hline Soldatova L [189] & $\begin{array}{l}\text { Virtual Dysphagia Evaluation: Practical Guidelines for } \\
\text { Dysphagia Management in the Context of the } \\
\text { COVID-19 Pandemic }\end{array}$ & USA & $\mathrm{HIC}$ & Institutional & Healthcare Workers \\
\hline Sommer D D [190] & $\begin{array}{l}\text { Recommendations From The Cso-Hns Taskforce On } \\
\text { Performance Of Tracheotomy During The Covid-19 } \\
\text { Pandemic }\end{array}$ & Canada & $\mathrm{HIC}$ & Institutional & Healthcare Workers \\
\hline Sonali Advani [26] & $\begin{array}{l}\text { Universal Masking in Hospitals in the COVID-19 era: } \\
\text { Is it Time to consider Shielding? }\end{array}$ & USA & $\mathrm{HIC}$ & National & Healthcare Workers \\
\hline Sorbello M [191] & $\begin{array}{l}\text { The Italian coronavirus disease } 2019 \text { outbreak: } \\
\text { recommendations from clinical practice }\end{array}$ & Italy & $\mathrm{HIC}$ & National & Population Wide \\
\hline Spinazzè A [192] & $\begin{array}{l}\text { Covid-19 Outbreak In Italy: Protecting Worker Health } \\
\text { And The Response Of The Italian Industrial } \\
\text { Hygienists Association }\end{array}$ & Italy & $\mathrm{HIC}$ & Institutional & $\begin{array}{l}\text { Healthcare Workers, } \\
\text { Essential Workers and } \\
\text { Population Wide }\end{array}$ \\
\hline Steward J E [193] & $\begin{array}{l}\text { Urologic Surgery And Covid-19: How The Pandemic } \\
\text { Is Changing The Way We Operate }\end{array}$ & USA & $\mathrm{HIC}$ & Institutional & Healthcare Workers \\
\hline Sunjaya A P [196] & Rationale For Universal Face Masks In Public Against & Australia & $\mathrm{HIC}$ & National & Population Wide \\
\hline
\end{tabular}


Table 1 Characteristics of The Included Policy Documents (Continued)

\begin{tabular}{|c|c|c|c|c|c|}
\hline Author and Year & Title & Country & $\begin{array}{l}\text { HIC/ } \\
\text { LMIC }\end{array}$ & Implementation & Target \\
\hline & Covid-19 & & & & \\
\hline Tan R M. R [197] & $\begin{array}{l}\text { Dynamic Adaptation To Covid-19 In A Singapore } \\
\text { Paediatric Emergency Department }\end{array}$ & Singapore & $\mathrm{HIC}$ & Institutional & Healthcare Workers \\
\hline $\begin{array}{l}\text { The American Academy } \\
\text { of Otolaryngology-Head } \\
\text { and Neck Surgery [30] }\end{array}$ & $\begin{array}{l}\text { AAO Position Statement: Tracheotomy } \\
\text { Recommendations During the COVID-19 Pandemic }\end{array}$ & USA & $\mathrm{HIC}$ & National & Healthcare Workers \\
\hline $\begin{array}{l}\text { The American } \\
\text { Gastroenterological } \\
\text { Association [194] }\end{array}$ & $\begin{array}{l}\text { AGA Rapid Recommendations for Gastrointestinal } \\
\text { Procedures During the COVID-19 Pandemic }\end{array}$ & USA & $\mathrm{HIC}$ & National & Healthcare Workers \\
\hline Thomas John P [198] & $\begin{array}{l}\text { Evaluating the national PPE guidance for NHS } \\
\text { healthcare workers during the COVID-19 pandemic }\end{array}$ & UK & $\mathrm{HIC}$ & National & Healthcare Workers \\
\hline Thomas P [199] & $\begin{array}{l}\text { Physiotherapy Management For Covid-19 In The } \\
\text { Acute Hospital Setting: Clinical Practice } \\
\text { Recommendations }\end{array}$ & Australia & $\mathrm{HIC}$ & Institutional & Healthcare Workers \\
\hline Turkistani K A [200] & $\begin{array}{l}\text { Precautions and recommendations for orthodontic } \\
\text { settings during the COVID-19 outbreak: A review }\end{array}$ & Saudi Arabia & $\mathrm{HIC}$ & Institutional & Healthcare Workers \\
\hline Van Gerven L [201] & $\begin{array}{l}\text { Personal Protection And Delivery Of Rhinologic And } \\
\text { Endoscopic Skull Base Procedures During The } \\
\text { Covid-19 Outbreak }\end{array}$ & $\begin{array}{l}\text { Belgium, UK } \\
\text { and Spain }\end{array}$ & $\mathrm{HIC}$ & Institutional & Healthcare Workers \\
\hline Vera C [44] & $\begin{array}{l}\text { Transmission risk of SARS-CoV-2 to healthcare } \\
\text { workers - observational results of a primary care } \\
\text { hospital contact tracing }\end{array}$ & Switzerland & $\mathrm{HIC}$ & Institutional & Healthcare Workers \\
\hline Wallace M [202] & $\begin{array}{l}\text { Public Health Response to COVID-19 Cases in Cor- } \\
\text { rectional and Detention Facilities - Louisiana, } \\
\text { March-April } 2020\end{array}$ & USA & $\mathrm{HIC}$ & Institutional & $\begin{array}{l}\text { Correctional and } \\
\text { detention facility } \\
\text { Administrators }\end{array}$ \\
\hline Walsh C M [203] & $\begin{array}{l}\text { Pediatric Endoscopy in the Era of Coronavirus } \\
\text { Disease 2019: A North American Society for } \\
\text { Pediatric Gastroenterology, Hepatology, and } \\
\text { Nutrition Position Paper }\end{array}$ & USA & $\mathrm{HIC}$ & Institutional & Healthcare Workers \\
\hline Wan Y L [204] & $\begin{array}{l}\text { Preparedness and Best Practice in Radiology } \\
\text { Department for COVID-19 and Other Future Pan- } \\
\text { demics of Severe Acute Respiratory Infection }\end{array}$ & Taiwan and USA & $\mathrm{HIC}$ & Institutional & Healthcare Workers \\
\hline Wang Qiang [205] & $\begin{array}{l}\text { The Role Of Masks And Respirator Protection } \\
\text { Against Sars-Cov-2 }\end{array}$ & China & LMIC & National & Population Wide \\
\hline Wax R S [206] & $\begin{array}{l}\text { Practical Recommendations For Critical Care And } \\
\text { Anesthesiology Teams Caring For Novel Coronavirus } \\
\text { (2019-Ncov) Patients }\end{array}$ & Canada and UK & $\mathrm{HIC}$ & Institutional & Healthcare Workers \\
\hline Wells Patricia [63] & $\begin{array}{l}\text { Practical Considerations For The Emergency Delivery } \\
\text { Of Babies From Mothers With Confirmed Or } \\
\text { Suspected Covid-19 }\end{array}$ & USA & $\mathrm{HIC}$ & Institutional & Healthcare Workers \\
\hline Whiteside T [207] & $\begin{array}{l}\text { Redesigning Emergency Department Operations } \\
\text { Amidst A Viral Pandemic }\end{array}$ & $\begin{array}{l}\text { USA and Saudi } \\
\text { Arabia }\end{array}$ & $\mathrm{HIC}$ & Institutional & $\begin{array}{l}\text { Patients and healthcare } \\
\text { workers }\end{array}$ \\
\hline WHO [208] & $\begin{array}{l}\text { Advice on the use of masks for children in the } \\
\text { community in the context of COVID-19 }\end{array}$ & Global & $\begin{array}{l}\text { HIC } \\
\text { and } \\
\text { LMIC }\end{array}$ & Global & Population Wide \\
\hline WHO [209] & $\begin{array}{l}\text { Advice on the use of masks in the context of } \\
\text { COVID-19 }\end{array}$ & Global & $\begin{array}{l}\text { HIC } \\
\text { and } \\
\text { LMIC }\end{array}$ & Global & Population Wide \\
\hline WHO [211] & $\begin{array}{l}\text { Interim Guidance. Infection prevention and control } \\
\text { during health care when novel coronavirus (nCov) } \\
\text { infection is suspected }\end{array}$ & Global & $\begin{array}{l}\text { HIC } \\
\text { and } \\
\text { LMIC }\end{array}$ & Institutional & $\begin{array}{l}\text { Healthcare Workers, } \\
\text { Healthcare Managers } \\
\text { and Public Health } \\
\text { Officials }\end{array}$ \\
\hline $\mathrm{WHO}[210]$ & $\begin{array}{l}\text { Infection prevention and control for the safe } \\
\text { management of a dead body in the context of } \\
\text { COVID-19 }\end{array}$ & Global & $\begin{array}{l}\text { HIC } \\
\text { and } \\
\text { LMIC }\end{array}$ & Institutional & $\begin{array}{l}\text { Healthcare Workers, } \\
\text { Staff of Mortuaries and } \\
\text { Public Health Officials }\end{array}$ \\
\hline $\mathrm{WHO}[212]$ & Considerations for quarantine of contacts of COVID- & Global & HIC & Global & Population Wide \\
\hline
\end{tabular}


Table 1 Characteristics of The Included Policy Documents (Continued)

\begin{tabular}{|c|c|c|c|c|c|}
\hline Author and Year & Title & Country & $\begin{array}{l}\text { HIC/ } \\
\text { LMIC }\end{array}$ & Implementation & Target \\
\hline & 19 cases & & $\begin{array}{l}\text { and } \\
\text { LMIC }\end{array}$ & & \\
\hline WHO [213] & $\begin{array}{l}\text { Home care for patients with suspected or } \\
\text { confirmed COVID-19 and management of their } \\
\text { contacts }\end{array}$ & Global & $\begin{array}{l}\text { HIC } \\
\text { and } \\
\text { LMIC }\end{array}$ & Institutional & $\begin{array}{l}\text { Healthcare Workers, } \\
\text { Healthcare Managers } \\
\text { and Public Health } \\
\text { Officials }\end{array}$ \\
\hline WHO [214] & $\begin{array}{l}\text { Transmission of SARS-CoV-2: implications for infec- } \\
\text { tion prevention precautions }\end{array}$ & Global & $\begin{array}{l}\text { HIC } \\
\text { and } \\
\text { LMIC }\end{array}$ & Global & Population Wide \\
\hline WHO [215] & $\begin{array}{l}\text { Advice on the use of masks in the community, } \\
\text { during home care and in health care settings in the } \\
\text { context of the novel coronavirus ( } 2019-n C o V) \\
\text { outbreak: interim guidance, } 29 \text { January } 2020\end{array}$ & Global & $\begin{array}{l}\text { HIC } \\
\text { and } \\
\text { LMIC }\end{array}$ & Global & Population Wide \\
\hline WHO [216] & $\begin{array}{l}\text { Coronavirus disease (COVID-19) advice for the } \\
\text { public }\end{array}$ & Global & $\begin{array}{l}\text { HIC } \\
\text { and } \\
\text { LMIC }\end{array}$ & Global & Population Wide \\
\hline WHO [217] & Clinical management COVID-19 & Global & $\begin{array}{l}\text { HIC } \\
\text { and } \\
\text { LMIC }\end{array}$ & Global & Patients \\
\hline WHO [218] & $\begin{array}{l}\text { Infection prevention and control during health care } \\
\text { when novel coronavirus (nCov) infection is } \\
\text { suspected }\end{array}$ & Global & $\begin{array}{l}\text { HIC } \\
\text { and } \\
\text { LMIC }\end{array}$ & Global & Healthcare Workers \\
\hline WHO [219] & $\begin{array}{l}\text { Minimum requirements for infection prevention and } \\
\text { control programmes }\end{array}$ & Global & $\begin{array}{l}\text { HIC } \\
\text { and } \\
\text { LMIC }\end{array}$ & Global & $\begin{array}{l}\text { Healthcare Workers and } \\
\text { Hospital Visitors }\end{array}$ \\
\hline Wickemeyer J L [220] & $\begin{array}{l}\text { Evolving Management of COVID-19: A Multi- } \\
\text { institutional Otolaryngology Perspective }\end{array}$ & USA & $\mathrm{HIC}$ & Institutional & Healthcare Workers \\
\hline Wong D H. T [221] & $\begin{array}{l}\text { Risk stratification protocol to reduce consumption } \\
\text { of personal protective equipment for emergency } \\
\text { surgeries during COVID-19 pandemic }\end{array}$ & China & LMIC & Institutional & Healthcare Workers \\
\hline Wong J [222] & $\begin{array}{l}\text { Preparing for a COVID-19 pandemic: a review of op- } \\
\text { erating room outbreak response measures in a large } \\
\text { tertiary hospital in Singapore }\end{array}$ & Singapore & $\mathrm{HIC}$ & Institutional & Healthcare Workers \\
\hline Workman A D [223] & $\begin{array}{l}\text { Airborne Aerosol Generation During Endonasal } \\
\text { Procedures in the Era of COVID-19: Risks and } \\
\text { Recommendations }\end{array}$ & USA & $\mathrm{HIC}$ & Institutional & Healthcare Workers \\
\hline Wu H L [224] & $\begin{array}{l}\text { Facemask shortage and the novel coronavirus } \\
\text { disease (COVID-19) outbreak: Reflections on public } \\
\text { health measures }\end{array}$ & China & LMIC & National & Population Wide \\
\hline Xu C [225] & $\begin{array}{l}\text { Application of refined management in prevention } \\
\text { and control of the coronavirus disease } 2019 \\
\text { epidemic in non-isolated areas of a general hospital }\end{array}$ & China & LMIC & Institutional & Healthcare Workers \\
\hline Yang C Y [226] & $\begin{array}{l}\text { Hemodialysis Vascular Access Care During The } \\
\text { Covid-19 Pandemic }\end{array}$ & Taiwan & $\mathrm{HIC}$ & Institutional & $\begin{array}{l}\text { Patients and healthcare } \\
\text { workers }\end{array}$ \\
\hline Yao Wenlong [227] & $\begin{array}{l}\text { Emergency Tracheal Intubation In } 202 \text { Patients With } \\
\text { Covid-19 In Wuhan, China: Lessons Learnt And Inter- } \\
\text { national Expert Recommendations }\end{array}$ & China & LMIC & Institutional & $\begin{array}{l}\text { Patients and healthcare } \\
\text { workers }\end{array}$ \\
\hline Yao Xiaoyuan [68] & $\begin{array}{l}\text { Health protection guideline of passenger transport } \\
\text { stations and transportation facilities during COVID- } \\
19 \text { outbreak }\end{array}$ & China & LMIC & National & Transportation workers \\
\hline Yetmar Z A [228] & $\begin{array}{l}\text { Inpatient Care of Patients with COVID-19: A Guide } \\
\text { for Hospitalists }\end{array}$ & USA & $\mathrm{HIC}$ & Institutional & Healthcare Workers \\
\hline Yi-Fong Su [229] & $\begin{array}{l}\text { Masks And Medical Care: Two Keys To Taiwan'S } \\
\text { Success In Preventing Covid-19 Spread }\end{array}$ & Taiwan & $\mathrm{HIC}$ & National & Population Wide \\
\hline Ying Bo [69] & $\begin{array}{l}\text { Health protection guideline of schools and other } \\
\text { educational institutions during COVID-19 outbreak }\end{array}$ & China & LMIC & National & $\begin{array}{l}\text { Students and School } \\
\text { Workers }\end{array}$ \\
\hline
\end{tabular}


Table 1 Characteristics of The Included Policy Documents (Continued)

\begin{tabular}{|c|c|c|c|c|c|}
\hline Author and Year & Title & Country & $\begin{array}{l}\text { HIC/ } \\
\text { LMIC }\end{array}$ & Implementation & Target \\
\hline Zhang Liubo [70] & $\begin{array}{l}\text { Health protection guideline of mobile cabin } \\
\text { hospitals during COVID-19 outbreak }\end{array}$ & China & LMIC & National & Healthcare Workers \\
\hline Zhao H M [230] & $\begin{array}{l}\text { Recommendations for respiratory rehabilitation in } \\
\text { adults with COVID-19 }\end{array}$ & China & LMIC & Institutional & Healthcare Workers \\
\hline Zhao Yanjie [231] & $\begin{array}{l}\text { Radiology department strategies to protect } \\
\text { radiologic technologists against COVID19: } \\
\text { Experience from Wuhan }\end{array}$ & China & LMIC & Institutional & Healthcare Workers \\
\hline Zhou Z [232] & $\begin{array}{l}\text { Mask Is The Possible Key For Self-Isolation In Covid- } \\
19 \text { Pandemic }\end{array}$ & China & LMIC & National & Population Wide \\
\hline Zimmermann M [233] & $\begin{array}{l}\text { Approaches to the management of patients in oral } \\
\text { and maxillofacial surgery during COVID-19 } \\
\text { pandemic }\end{array}$ & Austria & $\mathrm{HIC}$ & Institutional & Healthcare Workers \\
\hline Zuo M Z [234] & $\begin{array}{l}\text { Expert Recommendations For Tracheal Intubation In } \\
\text { Critically III Patients With Noval Coronavirus Disease } \\
2019\end{array}$ & China & LMIC & Institutional & Healthcare Workers \\
\hline
\end{tabular}

171, 173-190, 192-195, 197-204, 206-211, 213, 215223, 225-231, 233, 234] (Fig. 3). The policy documents $(n=190)$ were then categorized in different strata based on the included "PROGRESS-Plus" component (Fig. 4). Most of the policy documents focused on "occupation" component of the PROGRESS-plus and included populations at higher risk of contracting COVID-19 such as healthcare workers, essential workers, transportation workers etc. Specifically, $85.79 \%(n=163)$ of the included policy documents had "occupation" as an equity component [23, 25-27, 29-32, 34-37, 40, 42-46, 48, 49, $51,53,54,58,60,62-68,70-74,76-81,83,85-88,90$, 91, 93, 96-99, 101-109, 112, 113, 115-117, 119-121, 123-126, 128, 130, 131, 133-136, 138, 139, 142-164,

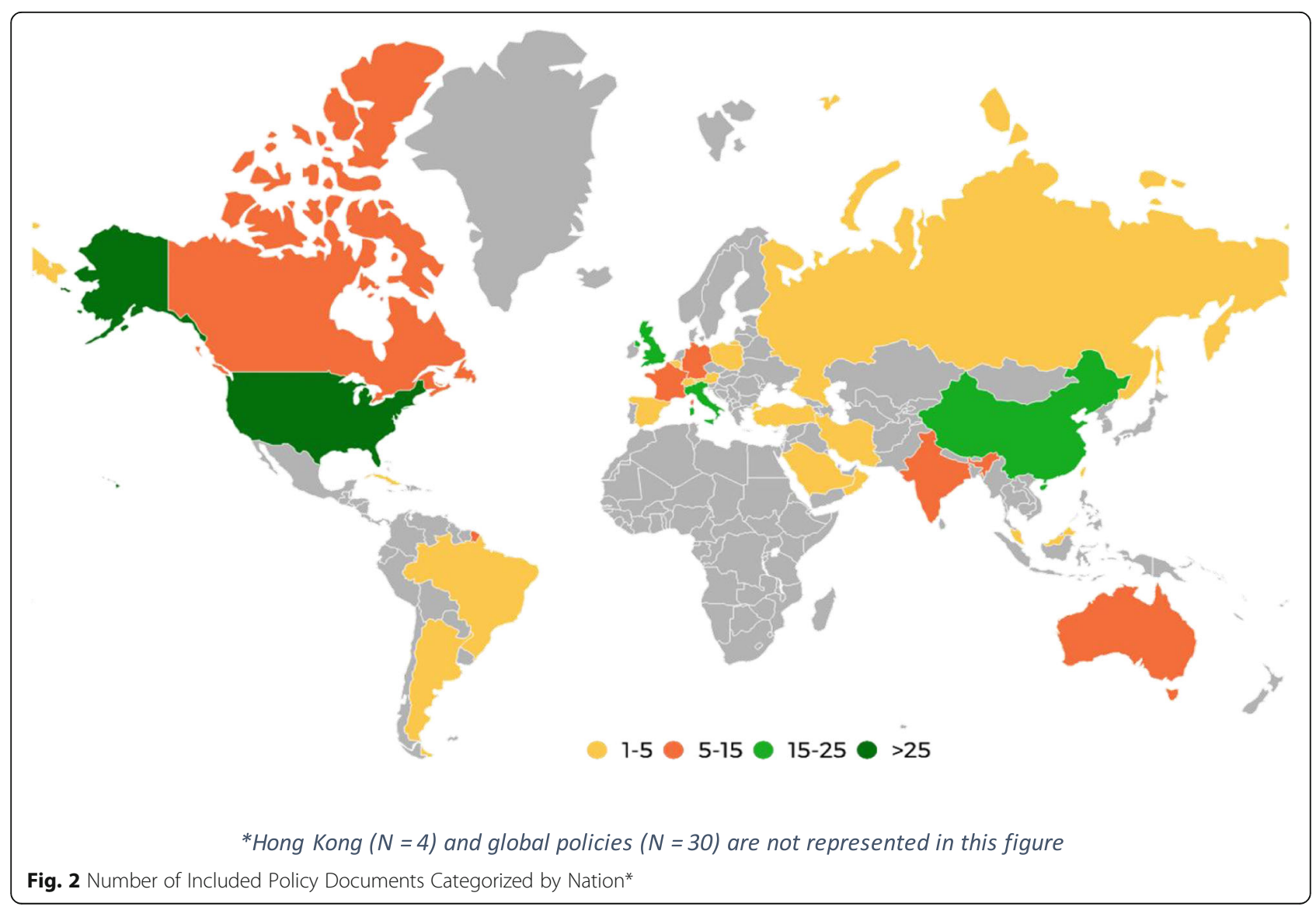




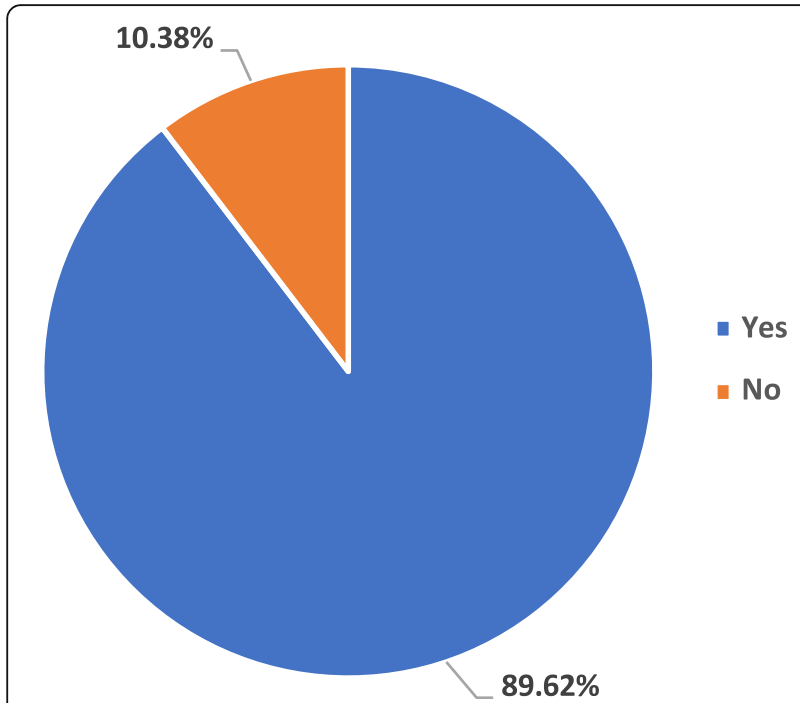

Fig. 3 Equity Incorporation (PROGRESS+) Assessment for Included Policy Documents

166-171, 173-184, 186-190, 192-195, 197-204, 206, 207, 210, 211, 213, 215, 217-223, 225-228, 230, 231, 234] followed by personal characteristics associated with discrimination $(n=4 ; 2.11 \%)[33,56,216,229]$, place of residence $(n=2 ; 1.05 \%)[75,114]$ and education $(\mathrm{n}=1$; 0.53\%) [69]. Several policy documents had mentioned multiple PROGRESS-Plus components. Specifically, 17 policy documents (8.95\%) mentioned two components of PROGRESS-Plus [28, 38, 39, 41, 47, 52, 57, 59, 82, 92, $110,111,122,127,137,185,233]$ and 3 policy documents $(1.58 \%)$ mentioned more than two components of the PROGRESS-plus framework [61, 208, 209] (Fig. 4).

Second, the strength of rationale to support inclusion of "PROGRESS-plus" factor in a policy document was analyzed. Of all the policy documents having equity component, 71 policy documents (37.37\%) explicitly provided the evidence for inclusion of PROGRESS-Plus component [25, 27, 28, 34, 36-38, 41, 42, 49, 58-61, 63, $64,66,71,74-77,82,86,91-93,104-106,111,112,114$,

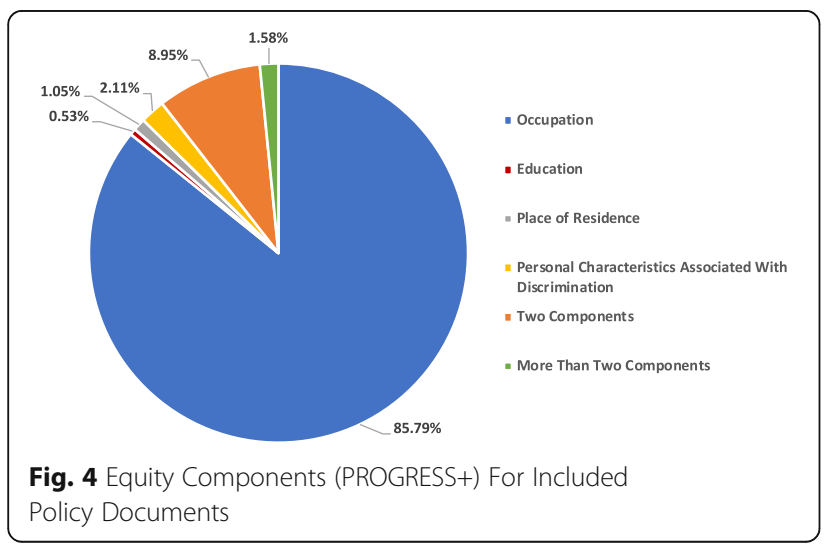

$121,122,124,126,127,130,131,134-137,144,146$, $148,155,159,160,166,167,171,176,177,180,182$, 185, 190, 192, 193, 197, 201, 206-208, 226, 227, 231, 233, 234] whereas rest did not provide any rationale for inclusion of PROGRESS-Plus component [23, 26, 29-33, $35,39,40,43-48,51-54,56,57,62,65,67-70,72,73$, 78-81, 83, 85, 87, 88, 90, 96-99, 101-103, 107-110, 113, $115-117,119,120,123,125,128,133,138,139,142$, $143,145,147,149-154,156-158,161-164,168-170$, $173-175,178,179,181,183,184,186-189,194,195$, 198-200, 202-204, 209-211, 213, 215-223, 225, 228230] (Fig. 5). Among these 71 policy documents, 47 were conducted in $\mathrm{HIC}[28,37,38,42,49,58,60,61,63,71$, 74, 76, 77, 82, 86, 91-93, 104-106, 112, 121, 122, 124, $127,130,135,137,144,148,159,167,171,176,180$, 182, 185, 190, 192, 193, 197, 201, 206, 207, 226, 233], 10 were conducted in LMIC [27, 36, 64, 111, 114, 136, 160, 227, 231, 234] and 14 were conducted in both HIC and LMIC $[25,34,41,59,66,75,126,131,134,146,155$, $166,177,208]$. In addition, most of these policy documents were targeted at workers $(n=66 ; 92.96 \%)[25,27$, 28, 34, 36-38, 41, 42, 49, 58, 60, 61, 63, 64, 66, 71, 74, 76, 77, 82, 86, 91-93, 104-106, 112, 121, 122, 124, 126, $127,130,131,134-137,144,146,148,155,159,160$, $166,167,171,176,177,180,182,185,190,192,193$, $197,201,206,207,226,227,231,233,234]$ and were implemented at institutional level $(n=62 ; 87.32 \%)[25,27$, $28,34,36-38,42,49,58,61,63,64,66,71,74,76,77$, $82,86,91,93,104-106,112,114,121,122,124,126$, $130,131,134-137,144,146,148,155,159,160,166$, $167,171,176,177,180,182,190,192,193,197,201$, 206, 207, 226, 227, 231, 233, 234].

Third, "indication level of equity" in policy documents was assessed. Our analysis found that only 2 policy documents $(1.05 \%)[75,209]$ had included terms related to equity and thus were deemed 'high level' whereas rest were considered to be of 'low level'.

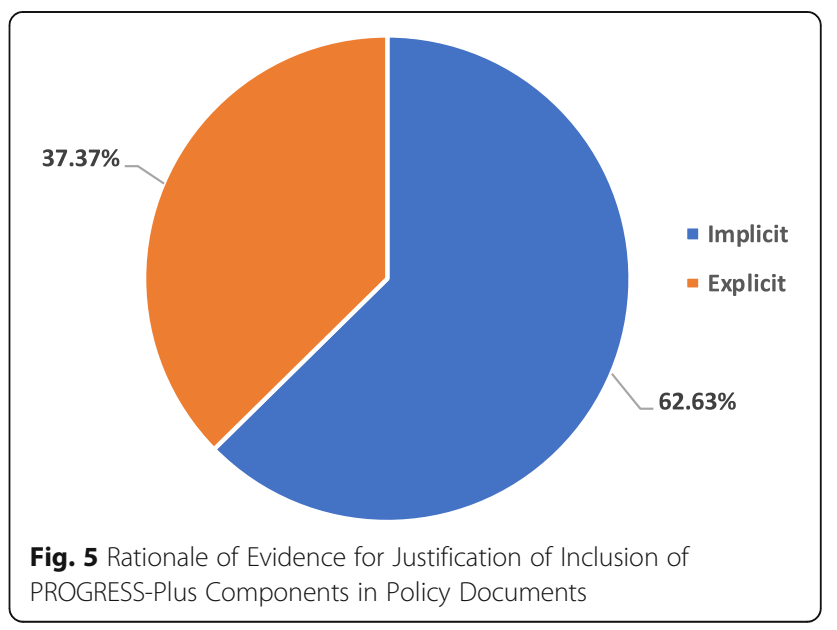




\section{Subgroup analysis}

For further analysis, policy documents were subdivided into two groups: policy documents targeted towards workers $(n=176$; 83.01\%) [23, 25-32, 34-49, 51, 53, 54, 57, 58, 60-74, 76-83, 85-88, 90-93, 96-99, 101-110, 112, $113,115-117,119-128,130,131,133-139,142-153$, 155-164, 166-171, 173-190, 192-195, 197-204, 206, 207, $210,211,213,218-223,225-228,230,231,233,234]$ and policy documents targeted towards everyone else $(n=36$; $16.98 \%)[24,33,50,52,55,56,59,75,84,89,94,95,100$, $111,114,118,129,132,140,141,154,165,172,191,196$, 205, 208, 209, 212, 214-217, 224, 229, 232]. The policy documents were divided as such because workers are usually provided masks/PPE as a part of safety protocol across different working environments such as healthcare setting, shopping centers, transportation centers etc. Among policy documents that were not targeted at workers, the target groups were: "patients" $(n=6 ; 2.80 \%)[55,56,94,100$, $132,217]$ and "population wide" $(n=30 ; 14.15 \%)[24,33$, 50, 52, 59, 75, 84, 89, 95, 111, 114, 118, 129, 140, 141, 154, 165, 172, 191, 196, 205, 208, 209, 212, 214-216, 224, 229 , 232].

As expected, all of the policy documents that were targeted towards workers had at least "occupation" component of the PROGRESS-Plus framework. Among policy documents that were not targeted at workers, 16 documents were conducted in HIC $[33,50,52,55,56,89,94$, $100,129,132,154,165,172,191,196,229], 8$ were conducted in LMIC $[24,84,111,114,118,205,224,232]$ and rest were conducted in HIC and LMIC $[59,75,95$, $140,141,208,209,212,214-217]$. In addition, most of these policy documents were implemented at national level $[24,33,50,52,55,56,84,94,111,129,154,165$, $191,196,205,224,229,232]$. As opposed to 'workers related' policy documents most of these remaining policy documents didn't have a PROGRESS-Plus equity component rendering them equity limiting. Specifically, 14 policy documents included consideration of a PROGRESS-Plus component [33, 52, 56, 59, 75, 111, 114, 154, 208, 209, 215-217, 229] whereas 22 policy documents didn't have a PROGRESS-plus component [24, 50, 55, 84, 89, 94, 95, 100, 118, 129, 132, 140, 141, 165, 172, 191, 196, 205, 212, 214, 224, 232]. Specifically, 4 policy documents had 'personal characteristics associated with discrimination' as a component $[33,56,216$, 229], 2 policy documents had 'place of residence' as a component [75, 114]; 3 policy documents had 'two components' [52, 59, 111]; and 2 policy documents had 'more than two components [208, 209]. Out of 14 policy documents that included a PROGRESS-Plus component $[33,52,56,59,75,111,114,154,208,209,215-217$, $229]$, only 5 policy documents explicitly mentioned the reason to include PROGRESS-plus component [59, 75, $111,114,208]$.

\section{Discussion}

To our knowledge, this is the first systematic review trying to ascertain the extent to which national, regional, institutional and organizational policies reflect equity considerations by focusing specifically on masks and personal protection equipment related policies. We have described the characteristics of the included policy documents including target population and implementation level among others. Most importantly, we have reported the equity factors considered within these policy documents using PROGRESS-plus equity framework. It is important to note that utilization of PROGRESS-plus framework for this research work is context specific and findings are limited to COVID-19 for most part. For instance, population types such as healthcare workers, essential workers are not usually considered vulnerable in society but in the context of COVID-19, increased risk of transmission of COVID-19 puts them at a disadvantage compared to the general population. Thus, findings of the research work should be interpreted within above mentioned scope.

Our review revealed that most of the included policy documents were from HIC. Specifically, we found that $64.15 \%$ policy documents were conducted/targeted towards HIC [26, 28-33, 37-40, 42-46, 48-58, 60, 61, 63, 71-74, 76, 77, 79-82, 85-94, 99-107, 110, 112, 113, 116, $117,119,121-124,127,129,130,132,135,137-139$, $143-145,147-154,156,158,159,161,163-165,167-$ 172, 174-176, 179-182, 184, 185, 188-204, 206, 207, $220,222,223,226,228,229,233] ; 18.40 \%$ were conducted/targeted towards LMIC [23, 24, 27, 35, 36, 47, $62,64,65,67-70,78,83,84,108,111,114,115,118$, $128,136,142,160,162,173,183,186,187,205,221$, $224,225,227,230-232,234]$ and $17.45 \%$ were conducted/targeted towards both HIC and LMIC countries $[25,34,41,59,66,75,95-98,109,120,125,126,131$, $133,134,140,141,146,155,157,166,177,178,208-$ 219]. In addition, our analysis found that most of the policy documents were implemented at an institutional level. Specifically, $69.81 \%$ of the policy documents were implemented at institutional level $[25,27-29,31,32$, $34-38,40,42-46,48,49,51,53,58,61-66,71,73,74$, $76-78,80-82,85,86,88-91,93,96,99-110,112-115$, $117,120-126,128,130-139,142-153,155-164,166-$ $168,171,173-184,186,188-190,192,193,197,199-$ 204, 206, 207, 210, 211, 213, 220-223, 225-228, 230, $231,233,234$ ] whereas $19.81 \%$ were implemented at national $[23,24,26,30,33,39,47,50,52,55-57,67-70$, $72,79,83,84,87,92,94,97,98,111,119,129,154,165$, $169,170,187,191,194-196,198,205,224,229,232]$ and only $10.38 \%$ were implemented at global level [41, $54,59,60,75,95,116,118,127,140,141,172,185,208$, 209, 212, 214-219]. These differences might be the result of variations in baseline risk, resources, health, and 
other system-level factors whether be at institutional or national level that hinder successful implementation of certain policies. For example, guidelines arising from HICs recommending the immediate upscaling of hospital care were not likely to be directly applicable to LMICs such as India because of an already overstretched medical system. In addition, mask mandates enacted in HICs were unlikely to be directly applicable to LMICs due to poverty related issues. Thus, policy makers should consider factors such as socioeconomic status, resource availability, place of residence while designing /implementing the policies. For example, Casola and colleagues [235] highlight that with $12 \%$ of US households living under the poverty line, many households may not have been able to purchase an adequate supply of masks for everyone in the household, or have the privilege of isolating at home while an adequate supply is delivered.

Equity assessment analysis revealed that most of the policy documents included only a single PROGRESSPlus equity component $(89.47 \%)$ [23, 25-27, 29-37, 40, $42-46,48,49,51,53,54,56,58,60,62-81,83,85-88$, 90, 91, 93, 96-99, 101-109, 112-117, 119-121, 123$126,128,130,131,133-136,138,139,142-164,166-$ 171, 173-184, 186-190, 192-195, 197-204, 206, 207, 210, 211, 213, 215-223, 225-231, 234]. This finding reflects that even if policy documents considered health inequity during the design/implementation, this consideration was very one dimensional in nature. There is significant evidence that determinants of health or health equity related factors coexist across different levels of society and can incur interactive and multiplicative effects among the most disadvantaged subpopulations [236, 237]. People from some racial and ethnic minority groups are more likely to be uninsured than nonHispanic whites [238]. Healthcare access can also be limited for these groups by many other factors, such as lack of transportation, child care, or ability to take time off of work; communication and language barriers; cultural differences between patients and providers; and historical and current discrimination in healthcare systems. Furthermore, inequities in access to high-quality education for some racial and ethnic minority groups can lead to lower high school completion rates and barriers to college entrance [239]. This may limit future job options and lead to lower paying or less stable jobs. These factors interacting together can not only increase the risk of these subpopulations to contract COVID-19 but also limit their ability to access good medical care. For instance, a poor (socioeconomic status) essential worker (occupation) in LMIC (place of residence) would be at a severe disadvantage of buying PPE/masks and protecting themselves from the transmission of COVID-19, and if contracted would be limited in getting treatment as well. Thus, policy makers should not only consider the presence of different equity related factors but also should consider the possible intersections between them while designing/implementing the policy.

Our review also revealed that very few policy documents acknowledged 'health equity' related issues in their text which illustrates that health equity was not a primary factor when these documents were being designed or implemented. Specifically, only 2 policy documents were found to have equity or inequity or health disparities in the aims, objectives or discussion. In addition, our assessment showed that, out of the selected documents, more than $10 \%$ of the policy documents [24, $50,55,84,89,94,95,100,118,129,132,140,141,165$, $172,191,196,205,212,214,224,232]$ had no PROGRESS-plus component mentioned or included in the policy. These findings indicate that significant proportion of policies were enacted with little to no emphasis on the 'health equity' mechanisms; which if enacted properly could have further improved the health outcomes for the society as whole.

Lastly, we analyzed the target population for the policies as well. Policy documents were subdivided into two groups: documents targeted towards workers. Our analysis found that majority of policy documents $(n=176$; 83.01\%) were targeted towards workers which was expected as they were at increased risk of contracting COVID-19 when compared to the general population. These targeted policies are usually equity enabling as workers are usually provided masks/PPE as a part of safety protocols across different working environments such as healthcare setting, shopping centers, transportation centers etc. and hence improve COVID-19 related health outcomes. Of the remaining 36 policy documents (16.98\%), most were targeted towards whole population $(n=30 ; 14.15 \%)[24,33,50,52,59,75,84,89,95,111$, $114,118,129,140,141,154,165,172,191,196,205$, 208, 209, 212, 214-216, 224, 229, 232]. Most of these policy documents did not include a PROGRESS-Plus equity component rendering them equity limiting for the society. These 'whole population' targeted policies should have considered equity as their success in improving COVID-19 related outcomes at a macro scale depends on a number of equity related factors such as education, gender, occupation, place of residence, socioeconomic status among others. Policy makers should identify relevant barriers to successful implementation of population wide policies while formulating such policies.

This study has several limitations that deserve mention. First, our search strategy was limited mainly to biomedical databases such as PubMed, EMBASE, CINAHL and Psycinfo with exceptions of ERIC and ASSIA. The search across a greater number of databases would have led to a substantial increase in the number of retrieved articles thus limiting the feasibility of the process. 
In order to address this limitation, we supplemented our search with the documents that were identified by searching the reference list of the documents. Second, it was beyond the remit of this study to assess the potential generalizability of a specific policy, although our analyses of PROGRESS-Plus characteristics indicates that this would have been challenging given that there was little consideration about equity in implementation and impacts within settings, let alone consideration about implementation across different settings. Third, the narrative nature of the findings did not allow us to perform a pooled analysis of any kind (e.g. on the implementation of $\mathrm{PPE} / \mathrm{masking}$ policies or their impact across different PROGRESS-Plus groups). Although such an analysis would be interesting for future research, this study addressed a different question around the consideration of health equity and inequity in COVID-19 policy and guideline development.

\section{Conclusion}

Policy makers should identify the importance of considering equity via PROGRESS-Plus components while devising guidelines for COVID-19 as these components affect both, risk of acquiring COVID-19 and the COVID-19 associated outcomes. Our review via focus on the masks/ PPE policies across the globe highlights that the consideration of equity if present is very, one dimensional in nature. In addition, population wide policies should be carefully designed and implemented after identifying relevant equity related barriers in order to produce better outcomes for the whole society. It is now clear that COVID19 has disproportionately impacted minoritised and disadvantaged groups and the pandemic has been characterised as killing unequally, with mitigation measures being experienced unequally, and will further impoverish unequally [240]. Our analysis here indicates some of the most important set of policies designed to limit the spread of the pandemic - policies around limiting the pandemic through masking and PPE - were all too frequently devised without equity considerations, and suggests that pandemic response measures were designed from a particular lens (high income country, white, and middle class). In contrast, advancing progress towards equity will generate social, cultural, economic, and environmental wellbeing for the whole society.

\section{Supplementary Information}

The online version contains supplementary material available at https://doi. org/10.1186/s12889-021-11688-7.

Additional file 1: Table S1. PRISMA Checklist. Table S2. Search

Strategy.

Acknowledgements

None.
Authors' contributions

Nathorn Chaiyakunapruk and Mukdarut Bangpan contributed to the study conception. Nathorn Chaiyakunapruk, Mukdarut Bangpan, Dylan Kneale and Vivian Welch contributed to the study design and oversight. Anindit

Chhibber and Aditi Kharat performed literature search and data extraction. Anindit Chhibber and Aditi Kharat performed data analysis. The first draft of the manuscript was written by Anindit Chhibber and Aditi Kharat and all authors commented on the following versions of the manuscript. All authors read and approved the final manuscript.

\section{Funding}

No specific funding was received from any bodies in the public, commercial or not-for-profit sectors to carry out the work described in this article.

\section{Availability of data and materials}

All data generated or analyzed during this study are included in this published article and its supplementary information files.

\section{Declarations}

Ethics approval and consent to participate

Not applicable.

Consent for publication

Not applicable.

\section{Competing interests}

Anindit Chhibber reports no potential conflict of interest. Aditi Kharat reports no potential conflict of interest. Dylan Kneale reports no potential conflict of interest. Vivian Welch reports no potential conflict of interest. Mukdarut Bangpan reports no potential conflict of interest. Nathorn Chaiyakunapruk reports no potential conflict of interest.

\section{Author details}

${ }^{1}$ School of Pharmacy, University of Utah, Salt Lake City, UT, USA. ${ }^{2}$ The Evidence for Policy and Practice Information and Co-ordinating Centre (EPPI-Centre), UCL Social Research Institute, University College London, London, UK. ${ }^{3}$ Bruyere Research Institute, Ottawa, Canada. ${ }^{4}$ School of Epidemiology and Public Health, University of Ottawa, Ottawa, Ontario, Canada. ${ }^{5}$ School of Pharmacy, Monash University, Subang Jaya, Malaysia.

Received: 7 May 2021 Accepted: 29 August 2021

Published online: 16 September 2021

\section{References}

1. WHO. Origins of the SARS-CoV-2 virus. 2021; Available from: https://www. who.int/health-topics/coronavirus/origins-of-the-virus.

2. Greenhalgh T, et al. Ten scientific reasons in support of airborne transmission of SARS-CoV-2. Lancet. 2021;397(10285):1603-5.

3. Centers for Disease Control and Prevention. Scientific Brief: SARS-CoV-2 Transmission. 2021; Available from: https://www.cdc.gov/coronavirus/2019ncov/science/science-briefs/sars-cov-2-transmission.html.

4. Worldometer. COVID-19 CORONAVIRUS PANDEMIC. 2021; Available from: https://www.worldometers.info/coronavirus/.

5. CDC. COVID-19 Hospitalization and Death by Race/Ethnicity. 2020; Available from: https://www.cdc.gov/coronavirus/2019-ncov/covid-data/investiga tions-discovery/hospitalization-death-by-race-ethnicity.html.

6. CDC. Older Adults At greater risk of requiring hospitalization or dying if diagnosed with COVID-19. 2020; Available from: https://www.cdc.gov/ coronavirus/2019-ncov/need-extra-precautions/older-adults.html.

7. Nguyen LH, et al. Risk of COVID-19 among front-line health-care workers and the general community: a prospective cohort study. Lancet Public Health. 2020;5(9):e475-83.

8. Brauner, J.M., et al., The effectiveness of eight nonpharmaceutical interventions against COVID-19 in 41 countries. medRxiv, 2020: 2020.05.28. 20116129 .

9. Flaxman $\mathrm{S}$, et al. Estimating the effects of non-pharmaceutical interventions on COVID-19 in Europe. Nature. 2020;584(7820):257-61. 
10. Hartley DM, Perencevich EN. Public health interventions for COVID-19: emerging evidence and implications for an evolving public health crisis. JAMA. 2020;323(19):1908-9.

11. Lai $\mathrm{S}$, et al. Effect of non-pharmaceutical interventions to contain COVID-19 in China. Nature. 2020;585(7825):410-3.

12. Moher $\mathrm{D}$, et al. Preferred reporting items for systematic review and metaanalysis protocols (PRISMA-P) 2015 statement. Syst Rev. 2015;4:1.

13. Page MJ, et al. The PRISMA 2020 statement: an updated guideline for reporting systematic reviews. Int J Surg. 2021;88:105906.

14. Sohrabi C, et al. PRISMA 2020 statement: What's new and the importance of reporting guidelines. Int J Surg. 2021;88:105918.

15. Page MJ, et al. The PRISMA 2020 statement: an updated guideline for reporting systematic reviews. J Clin Epidemiol. 2021;134:178-89.

16. Page MJ, et al. The PRISMA 2020 statement: an updated guideline for reporting systematic reviews. BMJ. 2021;372:n71

17. Page MJ, et al. The PRISMA 2020 statement: an updated guideline for reporting systematic reviews. Syst Rev. 2021;10(1):89.

18. Page MJ, et al. The PRISMA 2020 statement: an updated guideline for reporting systematic reviews. PLoS Med. 2021;18(3):e1003583.

19. Page MJ, et al. Updating guidance for reporting systematic reviews: development of the PRISMA 2020 statement. J Clin Epidemiol. 2021;134: 103-12.

20. O'Neill J, et al. Applying an equity lens to interventions: using PROGRESS ensures consideration of socially stratifying factors to illuminate inequities in health. J Clin Epidemiol. 2014;67(1):56-64.

21. Welch VA, Jull J, Hartling L, Klassen T, Kristjansson E, Pardo Pardo J, et al. Chapter 16: Equity and specific populations. In: JPT TJH, Chandler J, Cumpston M, Li T, Page MJ, Welch VA, editors. Cochrane Handbook for Systematic Reviews of Interventions version 6.1 (updated September 2020); 2020. Cochrane, 2020 .

22. Thomas J, Graziosi S, Brunton J, Ghouze Z, O'Driscoll P, Bond M. EPPIreviewer: advanced software for systematic reviews, maps and evidence synthesis. 2020. Available from: https://eppi.ioe.ac.uk/cms/Default.aspx?ta bid $=2967$.

23. Wei PF. Diagnosis and Treatment Protocol for Novel Coronavirus Pneumonia (Trial Version 7). Chin Med J (Engl). 2020;133(9):1087-95.

24. Abdi M. Coronavirus disease 2019 (COVID-19) outbreak in Iran: actions and problems. Infect Control Hosp Epidemiol. 2020;41(6):754-5. https://doi.org/1 0.1017/ice.2020.86.

25. Abramowicz JS, et al. ISUOG safety committee position statement on use of personal protective equipment and hazard mitigation in relation to SARSCoV-2 for practitioners undertaking obstetric and gynecological ultrasound. Ultrasound Obstet Gynecol. 2020;55(6):886-91.

26. Advani SD, et al. Universal masking in hospitals in the COVID-19 era: is it time to consider shielding? Infect Control Hosp Epidemiol. 2020;41(9):10667.

27. Agalar C, Ozturk Engin D. Protective measures for COVID-19 for healthcare providers and laboratory personnel. Turk J Med Sci. 2020;50(SI-1):578-84

28. Amatya $\mathrm{S}$, et al. Management of newborns exposed to mothers with confirmed or suspected COVID-19. J Perinatol. 2020:40(7):987-96.

29. American Academy of Opthalmology. Important coronavirus updates for ophthalmologists. 2020; Available from: https://www.aao.org/headline/alertimportant-coronavirus-context.

30. American Academy of Otolaryngology. AAO Position Statement: Tracheotomy Recommendations During the COVID-19 Pandemic. 2020; Available from: https://www.entnet.org/content/aao-position-statement-tra cheotomy-recommendations-during-covid-19-pandemic\#: :text=AAO\%2 OPosition\%20Statement\%3A\%20Tracheotomy\%20Recommendations\%2 ODuring\%20the\%20COVID\%2D19\%20Pandemic,AAO\%20Position\%20Sta tement\&text=To\%20establish\%20tracheotomy\%20recommendations\%20tha t,protective\%20equipment\%20(PPE)\%20depletion.

31. American Academy of Pediatrics. Management of Infants Born to Mothers with COVID-19. 2020; Available from: https://www.tn.gov/content/dam/tn/ health/documents/cedep/novel-coronavirus/AAP_COVID-19-Initial-NewbornGuidance.pdf.

32. American College of Cardiology's Interventional Council \& the Society for Cardiovascular Angiography Interventions. Catheterization Laboratory Considerations During the Coronavirus (COVID-19) Pandemic: From the ACC's Interventional Council and SCAI. J Am Coll Cardiol. 2020;75(18):2372-5.

33. American Geriatrics Society. American Geriatrics Society (AGS) policy brief: COVID-19 and assisted living facilities. J Am Geriatr Soc. 2020;68(6):1131-5.
34. AOCMF. AO CMF International Task Force Recommendations on Best Practices for Maxillofacial Procedures during COVID-19 Pandemic. 2020; Available from: https://www.aofoundation.org/what-we-do/covid-19resources-for-surgeons\#COVIDnews_o=News\%20Date\%20Facet,Descending.

35. Ashari MA, Zainal IA, Zaki FM. Strategies for radiology departments in handling the COVID-19 pandemic. Diagn Interv Radiol. 2020;26(4):296-300.

36. Ayan A, Kirac FS. Guide for nuclear medicine applications during the COVID19 outbreak. Mol Imaging Radionucl Ther. 2020;29(2):49-58.

37. Bann DV, et al. Impact of coronavirus (COVID-19) on otolaryngologic surgery: brief commentary. Head Neck. 2020;42(6):1227-34.

38. Bann DV, et al. Best practice recommendations for pediatric otolaryngology during the COVID-19 pandemic. Otolaryngol Head Neck Surg. 2020;162(6): 783-94.

39. Bein B, et al. SARS-CoV-2/COVID-19: evidence-based recommendations on diagnosis and therapy. Geburtshilfe Frauenheilkd. 2020;80(5):491-8.

40. Bianco F, et al. Preventing transmission among operating room staff during COVID-19 pandemic: the role of the aerosol box and other personal protective equipment. Updat Surg. 2020;72(3):907-10.

41. Bikson M, et al. Guidelines for TMS/tES clinical services and research through the COVID-19 pandemic. Brain Stimul. 2020;13(4):1124-49.

42. Boccalatte LA, et al. Brief guideline for the prevention of COVID-19 infection in head and neck and otolaryngology surgeons. Am J Otolaryngol. 2020; 41(3):102484

43. Canadian Association of Gastroenterology. COVID-19: Advice from the Canadian Association of Gastroenterology for Endoscopy Facilities, as of March 16, 2020. 2020; Available from: https://www.cag-acg.org/images/ publications/CAG-Statement-COVID-\&-Endoscopy.pdf.

44. Canova V, et al. Transmission risk of SARS-CoV-2 to healthcare workers -observational results of a primary care hospital contact tracing. Swiss Med Wkly. 2020;150:w20257.

45. Capanna F, et al. Preparing an obstetric unit in the heart of the epidemic strike of COVID-19: quick reorganization tips. J Matern Fetal Neonatal Med. 2020:1-7.

46. Cardinale F, et al. Consensus statement of the Italian society of pediatric allergy and immunology for the pragmatic management of children and adolescents with allergic or immunological diseases during the COVID-19 pandemic. Ital J Pediatr. 2020;46(1):84.

47. Carneiro A, et al. Impact of the COVID-19 pandemic on the Urologist's clinical practice in Brazil: a management guideline proposal for low- and middleincome countries during the crisis period. Int Braz J Urol. 2020;46(4):501-10.

48. Casiraghi $\mathrm{A}$, et al. Operational strategies of a trauma hub in early coronavirus disease 2019 pandemic. Int Orthop. 2020;44(8):1511-8.

49. Castelnuovo $P$, et al. Skull-base surgery during the COVID-19 pandemic: the Italian Skull Base society recommendations. Int Forum Allergy Rhinol. 2020; 10(8):963-7.

50. CDC, Coronavirus Disease 2019 (COVID-19). Frequently Asked Questions about Personal Protective Equipment. 2020

51. CDC. Use Personal Protective Equipment (PPE) When Caring for Patients with Confirmed or Suspected COVID-19. 2020; Available from: https://www. cdc.gov/coronavirus/2019-ncov/downloads/A_FS_HCP_COVID19_PPE.pdf.

52. CDC. Considerations for Wearing Masks To Help Slow Spread of COVID-19. 2020; Available from: https://www.cdc.gov/coronavirus/2019-ncov/preventgetting-sick/cloth-face-cover-guidance.html.

53. CDC. Criteria for Return to Work for Healthcare Personnel with SARS-CoV-2 Infection (Interim Guidance). 2020; Available from: https://www.cdc.gov/ coronavirus/2019-ncov/hcp/return-to-work.html.

54. CDC. Interim Infection Prevention and Control Recommendations for Healthcare Personnel During the Coronavirus Disease 2019 (COVID-19) Pandemic. 2020; Available from: https://www.cdc.gov/coronavirus/2019ncov/hcp/infection-control-recommendations.html.

55. CDC. Standard Precautions for All Patient Care. 2020; Available from: https:// www.cdc.gov/infectioncontrol/basics/standard-precautions.html.

56. CDC. Interim Clinical Guidance for Management of Patients with Confirmed Coronavirus Disease (COVID-19). 2020; Available from: https://stacks.cdc.gov/ view/cdc/89980

57. CDC. Interim Guidance on Management of Coronavirus Disease 2019 (COVID-19) in Correctional and Detention Facilities. 2020; Available from: https://www.cdc.gov/coronavirus/2019-ncov/community/correctiondetention/guidance-correctional-detention.html.

58. Chahar P, Dugar S, Marciniak D. Airway management considerations in patients with COVID-19. Cleve Clin J Med. 2020. https:/doi.org/10.3949/ccjm.87a.ccc033. 
59. Chan TK. Universal masking for COVID-19: evidence, ethics and recommendations. BMJ Glob Health. 2020;5(5):e002819.

60. Chandra A, et al. Personal protective equipment (PPE) for vitreoretinal surgery during COVID-19. Eye (Lond). 2020;34(7):1196-9.

61. Chavez S, Long B, Koyfman A, Liang S. Coronavirus Disease (COVID-19): A primer for emergency physicians. Am J Emerg Med. 2021;44:220-9. ISSN 0735-6757. https://doi.org/10.1016/j.ajem.2020.03.036.

62. Chawla D, et al. Perinatal-neonatal management of COVID-19 infection guidelines of the Federation of Obstetric and Gynaecological Societies of India (FOGSI), National Neonatology Forum of India (NNF), and Indian academy of pediatrics (IAP). Indian Pediatr. 2020;57(6):536-48.

63. Chen $\mathrm{D}$, et al. Expert consensus for managing pregnant women and neonates born to mothers with suspected or confirmed novel coronavirus (COVID-19) infection. Int J Gynaecol Obstet. 2020;149(2):130-6.

64. Chen $W$, Huang $Y$. To protect health care workers better, to save more lives with COVID-19. Anesth Analg. 2020;131(1):97-101.

65. Chen XC, et al. Preventive and control measures for the coronavirus pandemic in clinical dentistry. Chin J Dent Res. 2020;23(2):99-104.

66. Chersich MF, et al. COVID-19 in Africa: care and protection for frontline healthcare workers. Glob Health. 2020;16(1):46.

67. Chinese Center for Disease Control Prevention. Health protection guideline of enterprises during COVID-19 outbreak. Zhonghua Yu Fang Yi Xue Za Zhi. 2020;54(4):346-8.

68. Chinese Center for Disease Control Prevention. Health protection guideline of passenger transport stations and transportation facilities during COVID-19 outbreak. Zhonghua Yu Fang Yi Xue Za Zhi. 2020;54(4):359-61.

69. Chinese Center for Disease Control Prevention. Health protection guideline of schools and other educational institutions during COVID-19 outbreak. Zhonghua Yu Fang Yi Xue Za Zhi. 2020;54(4):348-50.

70. Chinese Center for Disease Control Prevention. Health protection guideline of mobile cabin hospitals during COVID-19 outbreak. Zhonghua Yu Fang Yi Xue Za Zhi. 2020;54(4):357-9.

71. Ciavattini A, Delli Carpini G, Giannella L, de Vincenzo R, Frega A, Cattani $P$, et al. Expert consensus from the Italian Society for Colposcopy and Cervico-Vaginal Pathology (SICPCV) for colposcopy and outpatient surgery of the lower genital tract during the COVID19 pandemic. Int J Gynaecol Obstet. 2020;149(3):269-72. https://doi. org/10.1002/ijgo.13158.

72. CMS. CMS Issues Recommendations to Re-Open Health Care Systems in Areas with Low Incidence of COVID-19. 2020; Available from: https://www. cms.gov/newsroom/press-releases/cms-issues-recommendations-re-openhealth-care-systems-areas-low-incidence-covid-19.

73. Coccolini F, et al. Surgery in COVID-19 patients: operational directives. World J Emerg Surg. 2020;15(1):25.

74. Copland M, et al. Canadian Society of Nephrology COVID-19 rapid response team home Dialysis recommendations. Can J Kidney Health Dis. 2020;7: 2054358120928153.

75. Corburn J, et al. Slum health: arresting COVID-19 and improving well-being in urban informal settlements. J Urban Health. 2020;97(3):348-57.

76. Couloigner $V$, et al. COVID-19 and ENT surgery. Eur Ann Otorhinolaryngol Head Neck Dis. 2020:137(3):161-6.

77. Crosby DL, Sharma A. Evidence-based guidelines for Management of Head and Neck Mucosal Malignancies during the COVID-19 pandemic. Otolaryngol Head Neck Surg. 2020;163(1):16-24.

78. Cui $C$, et al. Approaching otolaryngology patients during the COVID-19 pandemic. Otolaryngol Head Neck Surg. 2020;163(1):121-31.

79. Curigliano G. How to guarantee the best of care to patients with Cancer during the COVID-19 epidemic: the Italian experience. Oncologist. 2020; 25(6):463-7.

80. D'Aguanno V, et al. Clinical recommendations for epistaxis management during the COVID-19 pandemic. Otolaryngol Head Neck Surg. 2020;163(1): $75-7$.

81. Davenport MS, et al. ACR statement on safe resumption of routine radiology care during the coronavirus disease 2019 (COVID-19) pandemic. J Am Coll Radiol. 2020;17(7):839-44.

82. Day AT, et al. Head and neck oncology during the COVID-19 pandemic: reconsidering traditional treatment paradigms in light of new surgical and other multilevel risks. Oral Oncol. 2020;105:104684.

83. Deepthi R, et al. Personal Protective Equipments (PPE) - Prerequisites, Rationale and Challenges during COVID 19 Pandemic. Indian J Community Health. 2020;32(2 (Supp)):196-205.
84. Demirbilek Y, et al. COVID-19 outbreak control, example of ministry of health of Turkey. Turk J Med Sci. 2020;50(SI-1):489-94.

85. Desai U, Kassardjian CD, del Toro D, Gleveckas-Martens N, Srinivasan J, Venesy D, et al. Guidance for resumption of routine electrodiagnostic testing during the COVID-19 pandemic. Muscle Nerve. 2020;62(2):176-81. https://doi.org/10.1002/mus.26990.

86. DeSerres JJ, al-Shaqsi SZ, Antonyshyn OM, Fialkov JA. Best practice guidelines for the Management of Acute Craniomaxillofacial Trauma during the COVID-19 pandemic. J Craniofac Surg. 2020;31(6):e626-30. https://doi. org/10.1097/SCS.0000000000006654.

87. Deutsche Gesellschaft für Palliativmedizin. Recommendations for treatment of patients with COVID-19 from the palliative care perspective V2.0. 2020; Available from: https://www.dgpalliativmedizin.de/images/DGP_Ha ndlungsempfehlung_palliative_Therapie_bei_COVID18_V2.0_English_ version.pdf.

88. Dexter F, et al. Perioperative COVID-19 defense: an evidence-based approach for optimization of infection control and operating room management. Anesth Analg. 2020;131(1):37-42.

89. Di Saverio S, et al. Coronavirus pandemic and colorectal surgery: practical advice based on the Italian experience. Color Dis. 2020;22(6):625-34.

90. Do $\mathrm{MH}$, et al. Recommendations for personal protective equipment and smoke evacuation for dermatologic surgeries amid the COVID-19 crisis. Dermatol Ther. 2020;33(4):e13592.

91. Dockery DM, et al. The ocular manifestations and transmission of COVID-19: recommendations for prevention. J Emerg Med. 2020;59(1):137-40.

92. Dyal JW, Grant MP, Broadwater K, et al. COVID-19 Among Workers in Meat and Poultry Processing Facilities - 19 States, April 2020. MMWR Morb Mortal Wkly Rep. 2020;69:557-61. https://doi.org/10.15585/mmwr.mm691 8e3externalicon.

93. Elli $L$, et al. Endoscopy during the Covid-19 outbreak: experience and recommendations from a single center in a high-incidence scenario. Dig Liver Dis. 2020;52(6):606-12.

94. Esposito S, Principi N. To mask or not to mask children to overcome COVID19. Eur J Pediatr. 2020;179(8):1267-70.

95. Esposito $\mathrm{S}$, et al. Universal use of face masks for success against COVID-19: evidence and implications for prevention policies. Eur Respir J. 2020;55(6): 2001260.

96. European Center For Disease Prevention And Control. Infection Prevention and Control For the Care of Patients With 2019-nCoV in Healthcare Setting. 2020; Available from: https://www.ecdc.europa.eu/sites/default/files/ documents/nove-coronavirus-infection-prevention-control-patients-healthca re-settings.pdf.

97. European Center For Disease Prevention and Control. Infection prevention and control for the care of patients with 2019-nCoV in healthcare settings 2020; Available from: https://www.ecdc.europa.eu/sites/default/files/ documents/nove-coronavirus-infection-prevention-control-patients-healthca re-settings.pdf.

98. European Centre for Disease Prevention and Control. Infection prevention and control and preparedness for COVID-19 in healthcare settings - fourth update. 2020; Available from: https://www.ecdc.europa.eu/sites/default/files/ documents/Infection-prevention-and-control-in-healthcare-settings-COVID-1 9_4th_update.pdf.

99. Fananapazir $\mathrm{G}$, et al. Reorganizing cross-sectional interventional procedures practice during the coronavirus disease (COVID-19) pandemic. AJR Am J Roentgenol. 2020;215(6):1499-503.

100. Fawley N, Abdelmalak B. Procedural sedation in the COVID-19 era. Cleve Clin J Med. 2020. https://doi.org/10.3949/ccjm.87a.ccc043. Epub ahead of print. PMID: 32513808

101. Fillingham $Y A$, et al. Personal protective equipment: current best practices for orthopedic teams. J Arthroplast. 2020;35(7S):S19-22.

102. Forrester JD, et al. Precautions for operating room team members during the COVID-19 pandemic. J Am Coll Surg. 2020;230(6):1098-101.

103. Francis N, Dort J, Cho E, Feldman L, Keller D, Lim R, et al. SAGES and EAES recommendations for minimally invasive surgery during COVID-19 pandemic. Surg Endosc. 2020;34(6):2327-31. https://doi.org/10.1007/s00464020-07565-w.

104. Friese $C R$, et al. Respiratory protection considerations for healthcare workers during the COVID-19 pandemic. Health Secur. 2020;18(3):237-40.

105. Furfaro $F$, et al. SFED recommendations for IBD endoscopy during COVID-19 pandemic: Italian and French experience. Nat Rev Gastroenterol Hepatol. 2020;17(8):507-16 
106. Gackowski A, et al. Echocardiography during the coronavirus disease 2019 (COVID-19) pandemic: expert opinion of the working group on echocardiography of the polish cardiac society. Kardiol Pol. 2020;78(4):357-63.

107. Galloro G, et al. Safety in digestive endoscopy procedures in the covid era recommendations in progres of the italian society of digestive endoscopy. Dig Liver Dis. 2020;52(8):800-7.

108. Gemicioglu B, et al. Turkish thoracic society experts consensus report: recommendations for pulmonary function tests during and after COVID 19 pandemic. Turk Thorac J. 2020;21(3):193-200.

109. George $M$, et al. Proposal of a timing strategy for cholesteatoma surgery during the COVID-19 pandemic. Eur Arch Otorhinolaryngol. 2020;277(9):2619-23.

110. Goh K, et al. Preparing your intensive care unit for the COVID-19 pandemic: practical considerations and strategies. Crit Care. 2020;24(1):215.

111. Gorry C. COVID-19 case detection: Cuba's active screening approach. MEDICC Rev. 2020;22(2):58-63.

112. Gosling AF, et al. Perioperative considerations for tracheostomies in the era of COVID-19. Anesth Analg. 2020;131(2):378-86.

113. Goverment of Canada. Infection prevention and control for COVID-19: Second interim guidance for acute healthcare settings. 2020; Available from: https://www.canada.ca/en/public-health/services/diseases/2019-novelcoronavirus-infection/health-professionals/infection-prevention-controlcovid-19-second-interim-guidance.html.

114. Gupta A, Kakkar R. Managing a COVID 19 patient at different health care and field level settings. Indian J Community Health. 2020;32(2 (Supp)):188-95.

115. Gupta $P$, et al. Neurosurgery and neurology practices during the novel COVID-19 pandemic: a consensus statement from India. Neurol India. 2020;68(2):246-54.

116. Ha JF. The COVID-19 pandemic, personal protective equipment and respirator: a narrative review. Int J Clin Pract. 2020;74(10):e13578.

117. Haines S, Caccamo A, Chan F, Galaso G, Catinchi A, Gupta PK. Practical considerations when performing Neurodiagnostic studies on patients with COVID-19 and other highly virulent diseases. Neurodiagnostic J. 2020;60(2): 78-95. https://doi.org/10.1080/21646821.2020.1756132.

118. Han G, Zhou YH. Possibly critical role of wearing masks in general population in controlling COVID-19. J Med Virol. 2020;92(10):1779-81. https://doi.org/10.1002/jmv.25886.

119. Healthcare Purchasing News. CDC Updates Recommendations For Healthcare Supply Of PPE. 2020; Available from: https:/www.hpnonline.com/infectionprevention/disposables-kits-drapes-ppe-instruments-textiles-etc/article/211253 02/cdc-updates-recommendations-for-healthcare-supply-of-ppe.

120. Heldwein $\mathrm{FL}$, et al. A systematic review on quidelines and recommendations for urology standard of care during the COVID-19 pandemic. Eur Urol Focus. 2020;6(5):1070-85.

121. Higginson R, et al. Paramedic use of PPE and testing during the COVID-19 pandemic. J Paramedic Pract. 2020;12(6):221-5.

122. Higginson $\mathrm{R}$, et al. Personal protective equipment and testing during the COVID-19 pandemic. Br J Cardiac Nursing. 2020;15(5):1-7.

123. Hirschmann MT, et al. COVID-19 coronavirus: recommended personal protective equipment for the orthopaedic and trauma surgeon. Knee Surg Sports Traumatol Arthrosc. 2020;28(6):1690-8.

124. Hsieh TY, et al. A guide to facial trauma triage and precautions in the COVID-19 pandemic. Facial Plast Surg Aesthet Med. 2020;22(3):164-9.

125. Hu-Friedy. Best practices for hand hygiene and face mask use; 2020.

126. lacucci $M$, et al. Endoscopy in inflammatory bowel diseases during the COVID-19 pandemic and post-pandemic period. Lancet Gastroenterol Hepatol. 2020;5(6):598-606.

127. Islam MS, et al. Current knowledge of COVID-19 and infection prevention and control strategies in healthcare settings: a global analysis. Infect Control Hosp Epidemiol. 2020;41(10):1196-206.

128. Jin $\mathrm{YH}$, et al. A rapid advice guideline for the diagnosis and treatment of 2019 novel coronavirus (2019-nCoV) infected pneumonia (standard version). Mil Med Res. 2020;7(1):4.

129. Jung F, et al. How we should respond to the coronavirus SARS-CoV-2 outbreak: a German perspective. Clin Hemorheol Microcirc. 2020;74:363-72.

130. Kabesch M, Roth S, Brandstetter S, Häusler S, Juraschko E, Weigl M, et al. Successful containment of Covid-19 outbreak in a large maternity and perinatal center while continuing clinical service. Pediatr Allergy Immunol. 2020;31(5):560-4. https://doi.org/10.1111/pai.13265

131. Kligerman MP, Vukkadala N, Tsang RKY, Sunwoo JB, Holsinger FC, Chan JYK, et al. Managing head and neck cancer patients with tracheostomy or laryngectomy during the COVID-19 pandemic. Head Neck. 2020;42(6):120913. https://doi.org/10.1002/hed.26171.
132. Kluge $S$, et al. German recommendations for treatment of critically ill patients with COVID-19-version 3 : S1-guideline. Anaesthesist. 2020;69(9): 653-64.

133. Korobelnik JF, et al. Guidance for anti-VEGF intravitreal injections during the COVID-19 pandemic. Graefes Arch Clin Exp Ophthalmol. 2020;258(6):114956.

134. Kowalski LP, et al. COVID-19 pandemic: effects and evidence-based recommendations for otolaryngology and head and neck surgery practice. Head Neck. 2020;42(6):1259-67.

135. Lammers MJW, Lea J, Westerberg BD. Guidance for otolaryngology health care workers performing aerosol generating medical procedures during the COVID-19 pandemic. J Otolaryngol Head Neck Surg. 2020;49(1):36.

136. Lavinsky J, et al. An update on COVID-19 for the otorhinolaryngologist - a Brazilian Association of Otolaryngology and Cervicofacial Surgery (ABORLCCF) position statement. Braz J Otorhinolaryngol. 2020:86(3):273-80.

137. Leboulanger N, et al. COVID-19 and ENT pediatric otolaryngology during the COVID-19 pandemic. Guidelines of the French Association of Pediatric Otorhinolaryngology (AFOP) and French Society of Otorhinolaryngology (SFORL). Eur Ann Otorhinolaryngol Head Neck Dis. 2020;137(3):177-81.

138. Leonardi R, Bellinzoni P, Broglia L, Colombo R, De Marchi D, Falcone L, Giusti G, Grasso V, Mantica G, Passaretti G, Proietti S, Russo A, Saitta G, Smelzo S, Suardi N, Gaboardi F. Hospital care in Departments defined as COVID-free: A proposal for a safe hospitalization protecting healthcare professionals and patients not affected by COVID-19. Arch Ital Urol Androl. 2020;92(2). https://doi.org/10.4081/aiua.2020.2.67. PMID: 32597101.

139. Lescanne E, van der Mee-Marquet N, Juvanon JM, Abbas A, Morel N, Klein $J M$, et al. Best practice recommendations: ENT consultations during the COVID-19 pandemic. Eur Ann Otorhinolaryngol Head Neck Dis. 2020;137(4): 303-8. https://doi.org/10.1016/j.anorl.2020.05.007.

140. Leung CC, et al. Mask wearing to complement social distancing and save lives during COVID-19. Int J Tuberc Lung Dis. 2020;24(6):556-8.

141. Leung CC, Lam TH, Cheng KK. Mass masking in the COVID-19 epidemic: people need guidance. Lancet. 2020;395(10228):945.

142. Li Z. How ophthalmologists should understand and respond to the current epidemic of novel coronavirus pneumonia. Chin J Exper Opthalmol. 2020; 38(03):267-72.

143. Lie SA, et al. Practical considerations for performing regional anesthesia: lessons learned from the COVID-19 pandemic. Can J Anaesth. 2020;67(7): 885-92.

144. Lim LW, et al. Sustainable practice of ophthalmology during COVID-19: challenges and solutions. Graefes Arch Clin Exp Ophthalmol. 2020;258(7): 1427-36.

145. Lockhart SL, et al. Personal protective equipment (PPE) for both anesthesiologists and other airway managers: principles and practice during the COVID-19 pandemic. Can J Anaesth. 2020;67(8):1005-15.

146. Matava CT, et al. Pediatric airway management in COVID-19 patients: consensus guidelines from the Society for Pediatric Anesthesia's pediatric difficult intubation collaborative and the Canadian pediatric anesthesia society. Anesth Analg. 2020;131(1):61-73.

147. Mattei A, et al. Guidelines of clinical practice for the management of swallowing disorders and recent dysphonia in the context of the COVID-19 pandemic. Eur Ann Otorhinolaryngol Head Neck Dis. 2020;137(3):173-5.

148. McGrath BA, et al. Multidisciplinary guidance for safe tracheostomy care during the COVID-19 pandemic: the NHS National Patient Safety Improvement Programme (NatPatSIP). Anaesthesia. 2020;75(12):1659-70.

149. Micali $\mathrm{G}$, et al. The Italian dermatologic community facing COVID-19 pandemic: recommendation from the Italian society of dermatology and venereology. G Ital Dermatol Venereol. 2020;155(2):123-5.

150. Mujoomdar A, et al. The Canadian Association for Interventional Radiology (CAIR) and Canadian Association of Radiologists (CAR) guidelines for interventional radiology procedures for patients with suspected or confirmed COVID-19. Can Assoc Radiol J. 2020;71(4):514-7.

151. Mupparapu M. Dental practitioners' role in the assessment and containment of coronavirus disease (COVID-19): evolving recommendations from the centers for disease control. Quintessence Int. 2020;51(5):349-50.

152. $\mathrm{Ng} \mathrm{JJ}$, et al. Experience from a Singapore tertiary hospital with restructuring of a vascular surgery practice in response to national and institutional policies during the COVID-19 pandemic. J Vasc Surg. 2020;72(4):1166-72.

153. NICE. COVID-19 rapid guideline: critical care in adults. 2020; Available from: https://www.nice.org.uk/quidance/ng159/resources/covid19-rapid-guidelinecritical-care-in-adults-pdf-66141848681413. 
154. NICE. COVID-19 rapid guideline: managing symptoms (including at the end of life) in the community. 2020; Available from: https://www.nice.org.uk/ guidance/ng163.

155. Nolan JP, et al. European resuscitation council COVID-19 guidelines executive summary. Resuscitation. 2020;153:45-55.

156. Ortega R, et al. Personal protective equipment and Covid-19. N Engl J Med. 2020;382(26):e105

157. Paez D, et al. COVID-19 pandemic: guidance for nuclear medicine departments. Eur J Nucl Med Mol Imaging. 2020;47(7):1615-9.

158. Palatnik A, McIntosh JJ. Protecting labor and delivery personnel from COVID-19 during the second stage of labor. Am J Perinatol. 2020;37(8):854-6.

159. Panesar K, et al. Evolution of COVID-19 guidelines for University of Washington Oral and maxillofacial surgery patient care. J Oral Maxillofac Surg. 2020;78(7):1136-46.

160. Panuganti BA, et al. Procedural precautions and personal protective equipment during head and neck instrumentation in the COVID-19 era. Head Neck. 2020;42(7):1645-51.

161. Patel V, Jimenez E, Cornwell L, Tran T, Paniagua D, Denktas AE, et al. Cardiac surgery during the coronavirus disease 2019 pandemic: perioperative considerations and triage recommendations. J Am Heart Assoc. 2020;9(13): e017042. https://doi.org/10.1161/JAHA.120.017042.

162. Patwa A, et al. All India difficult airway association (AIDAA) consensus guidelines for airway management in the operating room during the COVID-19 pandemic. Indian J Anaesthesia. 2020;64(14):107-15.

163. Peditto M, et al. Dentistry during the COVID-19 Epidemic: An Italian Workflow for the Management of Dental Practice. Int J Environ Res Public Health. 2020;17(9):3325.

164. Peraza-Smith G B. Imperative for a safe and healthy workplace for nurses. 2020; Available from: https://cdn.ymaws.com/www.floridanurse.org/ resource/resmgr/covid/FNA_COVID-19_PPE_Statement.pdf.

165. Perencevich EN, Diekema DJ, Edmond MB. Moving personal protective equipment into the community: face shields and containment of COVID-19. JAMA. 2020;323(22):2252-3

166. Perkins GD, et al. International liaison committee on resuscitation: COVID-19 consensus on science, treatment recommendations and task force insights. Resuscitation. 2020;151:145-7.

167. Pezzulla D, et al. Radiotherapy in southern Italy at the time of COVID-19: options for radiation oncology units. Int J Gynecologic Cancer. 2020;30(7):917.

168. Public Health England, COVID-19: Infection Prevention and Control Guidance. 2020

169. Public Health England. COVID-19: management of staff and exposed patients or residents in health and social care settings. 2020; Available from: https://www.gov.uk/government/publications/covid-19-management-ofexposed-healthcare-workers-and-patients-in-hospital-settings/covid-19-mana gement-of-exposed-healthcare-workers-and-patients-in-hospital-settings.

170. Public Health England. New recommendations for primary and community health care providers in England. 2020; Available from: https://www.gov.uk/ government/publications/wuhan-novel-coronavirus-infection-prevention-a nd-control/new-recommendations-for-primary-and-community-health-careproviders-in-england

171. Quah LJJ, et al. Reorganising the emergency department to manage the COVID-19 outbreak. Int J Emerg Med. 2020;13(1):32.

172. Raina Maclntyre C, Jay Hasanain S. Community universal face mask use during the COVID 19 pandemic-from households to travellers and public spaces. J Travel Med. 2020;27(3):taaa056.

173. Ramos RF, Lima DL, Benevenuto DS. Recommendations of the Brazilian College of Surgeons for laparoscopic surgery during the COVID-19 pandemic. Rev Col Bras Cir. 2020;47:e20202570.

174. Randelli PS, Compagnoni R. Management of orthopaedic and traumatology patients during the coronavirus disease (COVID-19) pandemic in northern Italy. Knee Surg Sports Traumatol Arthrosc. 2020;28(6):1683-9.

175. Rochelson B, et al. The care of pregnant women during the COVID-19 pandemic - response of a large health system in metropolitan New York. J Perinat Med. 2020;48(5):453-61.

176. Saadi RA, et al. A commentary on safety precautions for Otologic surgery during the COVID-19 pandemic. Otolaryngol Head Neck Surg. 2020;162(6): 797-9.

177. Saenz LC, et al. Recommendations for the organization of electrophysiology and cardiac pacing services during the COVID-19 pandemic : Latin American Heart Rhythm Society (LAHRS) in collaboration with: Colombian college of electrophysiology, Argentinian Society of Cardiac
Electrophysiology (SADEC), Brazilian society of cardiac arrhythmias (SOBRAC), Mexican Society of Cardiac Electrophysiology (SOMEEC). J Interv Card Electrophysiol. 2020;59(2):307-13.

178. San-Juan D, et al. Guidance for clinical neurophysiology examination throughout the COVID-19 pandemic. Latin American chapter of the IFCN task force - COVID-19. Clin Neurophysiol. 2020;131(7):1589-98.

179. Say DS, et al. Risk stratification and personal protective equipment use in pediatric endoscopy during the coronavirus disease 2019 outbreak: a singlecenter protocol. J Pediatr Gastroenterol Nutr. 2020;70(6):751-4.

180. Sayburn A. Covid-19: PHE upgrades PPE advice for all patient contacts with risk of infection. BMJ. 2020;369:m1391.

181. Schultz $P$, et al. French consensus regarding precautions during tracheostomy and post-tracheostomy care in the context of COVID-19 pandemic. Eur Ann Otorhinolaryngol Head Neck Dis. 2020;137(3):167-9.

182. Seely JM, Scaranelo AM, Yong-Hing C, Appavoo S, Flegg C, Kulkarni S, et al. COVID-19: safe guidelines for breast imaging during the pandemic. Can Assoc Radiol J. 2020;71(4):459-69. https://doi.org/10.1177/084653712092 8864

183. Sengupta S, et al. All India ophthalmological society - Indian journal of ophthalmology consensus statement on preferred practices during the COVID-19 pandemic. Indian J Ophthalmol. 2020;68(5):711-24.

184. Shaker MS, et al. COVID-19: Pandemic Contingency Planning for the Allergy and Immunology Clinic. J Allergy Clin Immunol Pract. 2020;8(5):1477-1488.e5.

185. Sharma V, Scott J, Kelly J, VanRooyen MJ. Prioritizing vulnerable populations and women on the frontlines: COVID-19 in humanitarian contexts. Int J Equity Health. 2020;19(1):66. https://doi.org/10.1186/s12939-020-01186-4.

186. Singh AG, Deodhar J, Chaturvedi P. Navigating the impact of COVID-19 on palliative care for head and neck cancer. Head Neck. 2020;42(6):1144-6.

187. Singh B, et al. Indian resuscitation council (IRC) suggested guidelines for comprehensive cardiopulmonary life support (CCLS) for suspected or confirmed coronavirus disease (COVID-19) patient. Indian J Anaesth. 2020; 64(Suppl 2):S91-6.

188. Sobel $\mathrm{D}$, et al. Personal protective equipment for common urologic procedures before and during the United States COVID-19 pandemic: a single institution study. Urology. 2020;141:1-6.

189. Soldatova $L$, et al. Virtual dysphagia evaluation: practical guidelines for dysphagia Management in the Context of the COVID-19 pandemic. Otolaryngol Head Neck Surg. 2020;163(3):455-8.

190. Sommer DD, et al. Recommendations from the CSO-HNS taskforce on performance of tracheotomy during the COVID-19 pandemic. J Otolaryngol Head Neck Surg. 2020;49(1):23.

191. Sorbello M, et al. The Italian coronavirus disease 2019 outbreak: recommendations from clinical practice. Anaesthesia. 2020;75(6):724-32

192. Spinazze A, Cattaneo A, Cavallo DM. COVID-19 outbreak in Italy: protecting worker health and the response of the Italian industrial hygienists association. Ann Work Expo Health. 2020;64(6):559-64.

193. Steward JE, Kitley WR, Schmidt CM, Sundaram CP. Urologic surgery and COVID-19: how the pandemic is changing the way we operate. J Endourol. 2020;34(5):541-9. https://doi.org/10.1089/end.2020.0342.

194. Sultan S, et al. AGA rapid recommendations for gastrointestinal procedures during the COVID-19 pandemic. Gastroenterology. 2020;159(2):739-58 e4

195. Sundaram M, et al. Novel coronavirus 2019 (2019-nCoV) infection: part II respiratory support in the pediatric intensive care unit in resource-limited settings. Indian Pediatr. 2020;57(4):335-42.

196. Sunjaya AP, Jenkins C. Rationale for universal face masks in public against COVID-19. Respirology. 2020;25(7):678-9.

197. Tan RMR, et al. Dynamic adaptation to COVID-19 in a Singapore paediatric emergency department. Emerg Med J. 2020;37(5):252-4.

198. Thomas JP, Srinivasan A, Wickramarachchi CS, Dhesi PK, Hung YMA, Kamath AV. Evaluating the national PPE guidance for NHS healthcare workers during the COVID-19 pandemic. Clin Med (Lond). 2020;20(3):242-7. https:// doi.org/10.7861/clinmed.2020-0143.

199. Thomas P, et al. Physiotherapy management for COVID-19 in the acute hospital setting: clinical practice recommendations. J Physiother. 2020;66(2): 73-82.

200. Turkistani KA. Precautions and recommendations for orthodontic settings during the COVID-19 outbreak: a review. Am J Orthod Dentofac Orthop. 2020:158(2):175-81.

201. Van Gerven L, et al. Personal protection and delivery of rhinologic and endoscopic skull base procedures during the COVID-19 outbreak. Rhinology. 2020;58(3):289-94 
202. Wallace M, et al. Public health response to COVID-19 cases in correctional and detention facilities - Louisiana, march-April 2020. MMWR Morb Mortal Wkly Rep. 2020;69(19):594-8.

203. Walsh CM, et al. Pediatric endoscopy in the era of coronavirus disease 2019 a north American Society for Pediatric Gastroenterology, hepatology, and nutrition position paper. J Pediatr Gastroenterol Nutr. 2020;70(6):741-50

204. Wan YL, et al. Preparedness and best practice in radiology Department for COVID-19 and other future pandemics of severe acute respiratory infection. J Thorac Imaging. 2020;35(4):239-45.

205. Wang Q, Yu C. The role of masks and respirator protection against SARSCoV-2. Infect Control Hosp Epidemiol. 2020;41(6):746-7.

206. Wax RS, Christian MD. Practical recommendations for critical care and anesthesiology teams caring for novel coronavirus (2019-nCoV) patients. Can J Anaesth. 2020;67(5):568-76

207. Whiteside T, et al. Redesigning emergency department operations amidst a viral pandemic. Am J Emerg Med. 2020;38(7):1448-53.

208. WHO. Advice on the use of masks for children in the community in the context of COVID-19 2020; Available from: https://www.who.int/publica tions/i/item/WHO-2019-nCoV-IPC_Masks-Children-2020.1.

209. WHO. Advice on the use of masks in the context of COVID-19. 2020; Available from: https://www.who.int/publications/i/item/advice-on-the-useof-masks-in-the-community-during-home-care-and-in-healthcare-settings-inthe-context-of-the-novel-coronavirus-(2019-ncov)-outbreak.

210. WHO. Infection prevention and control for the safe management of a dead body in the context of COVID-19. 2020; Available from: https://www.who. int/publications/i/item/infection-prevention-and-control-for-the-safe-mana gement-of-a-dead-body-in-the-context-of-covid-19-interim-guidance.

211. WHO. Interim Guidance. Infection prevention and control during health care when novel coronavirus (nCoV) infection is suspected. 2020; Available from: https://www.who.int/publications/i/item/10665-331495

212. WHO. Considerations for quarantine of contacts of COVID-19 cases. 2020; Available from: https://www.who.int/publications/i/item/considerations-forquarantine-of-individuals-in-the-context-of-containment-for-coronavirusdisease-(covid-19).

213. WHO. Home care for patients with suspected or confirmed COVID-19 and management of their contacts 2020; Available from: https://www.who.int/ publications/i/item/home-care-for-patients-with-suspected-novel-corona virus-(ncov)-infection-presenting-with-mild-symptoms-and-management-ofcontacts.

214. WHO. Transmission of SARS-CoV-2: implications for infection prevention precautions. 2020; Available from: https://www.who.int/publications/i/item/ modes-of-transmission-of-virus-causing-covid-19-implications-for-ipc-preca ution-recommendations

215. WHO. Advice on the use of masks in the community, during home care and in health care settings in the context of the novel coronavirus (2019nCoV) outbreak: interim guidance, 29 January 2020. 2020; Available from: https://apps.who.int/iris/handle/10665/330987.

216. WHO. Coronavirus disease (COVID-19) advice for the public. 2020; Available from: https://www.who.int/emergencies/diseases/novel-coronavirus-2019/a dvice-for-public.

217. WHO. Clinical management COVID-19. 2020; Available from: https://www. who.int/publications/i/item/clinical-management-of-covid-19.

218. WHO. Infection prevention and control during health care when nove coronavirus (nCov) infection is suspected. 2020; Available from: https:// www who.int/publications/i/item/10665-331495.

219. WHO. Minimum requirements for infection prevention and control programmes. 2020; Available from: https://www.who.int/infectionprevention/publications/min-req-IPC-manual/en/.

220. Wickemeyer JL, Billings KR, Valika TS. Evolving management of COVID-19: a multi-institutional otolaryngology perspective. Otolaryngol Head Neck Surg. 2020;163(2):259-64. https://doi.org/10.1177/0194599820930244.

221. Wong DHT, et al. Risk stratification protocol to reduce consumption of personal protective equipment for emergency surgeries during COVID-19 pandemic. Hong Kong Med J. 2020;26(3):252-4.

222. Wong J, et al. Preparing for a COVID-19 pandemic: a review of operating room outbreak response measures in a large tertiary hospital in Singapore Can J Anaesth. 2020;67(6):732-45

223. Workman AD, et al. Airborne aerosol generation during Endonasa procedures in the era of COVID-19: risks and recommendations. Otolaryngol Head Neck Surg. 2020;163(3):465-70.
224. Wu HL, et al. Facemask shortage and the novel coronavirus disease (COVID19) outbreak: reflections on public health measures. EClinicalMedicine. 2020; 21:100329.

225. Xu C, et al. Application of refined management in prevention and control of the coronavirus disease 2019 epidemic in non-isolated areas of a general hospital. Int J Nurs Sci. 2020;7(2):143-7.

226. Yang CY, et al. Hemodialysis vascular access care during the COVID-19 pandemic. J Chin Med Assoc. 2020;83(7):634-8.

227. Yao W, et al. Emergency tracheal intubation in 202 patients with COVID-19 in Wuhan, China: lessons learnt and international expert recommendations. $\mathrm{Br} J$ Anaesth. 2020;125(1):e28-37.

228. Yetmar ZA, et al. Inpatient Care of Patients with COVID-19: a guide for hospitalists. Am J Med. 2020;133(9):1019-24.

229. Yi-Fong Su V, et al. Masks and medical care: two keys to Taiwan's success in preventing COVID-19 spread. Travel Med Infect Dis. 2020;38:101780.

230. Zhao HM, et al. Recommendations for respiratory rehabilitation in adults with coronavirus disease 2019. Chin Med J. 2020;133(13):1595-602.

231. Zhao Y, et al. Radiology department strategies to protect radiologic technologists against COVID19: experience from Wuhan. Eur J Radiol. 2020; 127:108996.

232. Zhou Z, et al. Mask is the possible key for self-isolation in COVID-19 pandemic. J Med Virol. 2020:92(10):1745-6.

233. Zimmermann M, Nkenke E. Approaches to the management of patients in oral and maxillofacial surgery during COVID-19 pandemic. J Craniomaxillofac Surg. 2020;48(5):521-6

234. Zuo MZ, et al. Expert recommendations for tracheal intubation in critically il patients with Noval coronavirus disease 2019. Chin Med Sci J. 2020;35(2): 105-9.

235. Casola AR, et al. Mask use during COVID-19: a social-ecological analysis. Health Promot Pract. 2021;22(2):152-5.

236. Islam MM. Social determinants of health and related inequalities: confusion and implications. Front Public Health. 2019;7:11.

237. Ahnquist J, Wamala SP, Lindstrom M. Social determinants of health--a question of social or economic capital? Interaction effects of socioeconomic factors on health outcomes. Soc Sci Med. 2012;74(6):930-9.

238. Sohn $\mathrm{H}$. Racial and ethnic disparities in health insurance coverage: dynamics of gaining and losing coverage over the life-course. Popul Res Policy Rev. 2017;36(2):181-201.

239. Thomas KJ. Racial and ethnic disparities in education-occupation mismatch status among immigrants in South Africa and the United States. J Int Migr Integr. 2010;11(4):383-401.

240. Bambra C, Lynch J. The unequal pandemic: COVID-19 and health inequalities. Bristol: Policy Press; 2021

\section{Publisher's Note}

Springer Nature remains neutral with regard to jurisdictional claims in published maps and institutional affiliations.

Ready to submit your research? Choose BMC and benefit from

- fast, convenient online submission

- thorough peer review by experienced researchers in your field

- rapid publication on acceptance

- support for research data, including large and complex data types

- gold Open Access which fosters wider collaboration and increased citations

- maximum visibility for your research: over $100 \mathrm{M}$ website views per year

At BMC, research is always in progress.

Learn more biomedcentral.com/submissions 